\title{
Katılım Bankası Çalışanlarının Faizsiz Finans Muhasebe Standartlarına Bakış Açılarının Analizi: Sivas İli Örneği \\ (Analyzing The Perspectives of Participation Banks Towards Interest Free Financial Accounting Standards: The Case of Sivas Province)
}

\author{
Said Alpagut ŞENEL iD a Öznur ARSLAN iD $b$ \\ a Sivas Cumhuriyet Üniversitesi, İktisadi ve İdari Bilimler Fakültesi, Sivas, Türkiye. asenel@cumhuriyet.edu.tr \\ b Sivas Cumhuriyet Üniversitesi, Cumhuriyet Meslek Yüksekokulu, Sivas, Türkiye. oznurkul@cumhuriyet.edu.tr
}

\begin{tabular}{|c|c|}
\hline MAKALE BİLGİSİ & ÖZET \\
\hline $\begin{array}{l}\text { Anahtar Kelimeler: } \\
\text { Katılım Bankaları } \\
\text { Faizsiz Finans Muhasebe Stan- }\end{array}$ & $\begin{array}{l}\text { Amaç - Bu çalışma, Sivas il merkezinde faaliyet gösteren katılım bankası çalışanlarının faizsiz finans } \\
\text { muhasebe standartlarına yönelik farkındalık düzeylerini belirlemek ve faizsiz finans muhasebe stan- } \\
\text { dartlarının katılım bankalarında uygulanabilirliğine ilişkin düşüncelerini tespit etmek amacıyla yapıl- } \\
\text { mıştır. }\end{array}$ \\
\hline İslami Bankacılık & $\begin{array}{l}\text { Yöntem - Çalışmada veri toplama tekniği olarak anket yöntemi kullanılmıştır. Araştırmanın evrenini } \\
\text { Sivas il merkezinde faaliyet gösteren } 5 \text { katılım bankasında (Albaraka Türk Katılım Bankası, Kuveyt }\end{array}$ \\
\hline Faizsiz Finans Sitemi & $\begin{array}{l}\text { Türk Katılım Bankası, Türkiye Finans Katılım Bankası, Vakıf Katılım Bankası ve Ziraat Katılım Bankası) } \\
\text { çalışan kişiler oluşturmaktadır. Bu bağlamda Sivas ilinde faaliyet gösteren katılım bankaları persone- } \\
\text { linden } 60 \text { çalışanla yüz yüze görüşülerek } 53 \text { çalışana anket uygulanmıştır. Anket verilerinin analizinde, } \\
\text { SPSS } 22 \text { for Windows (Social Package Statiscal Science) istatistiksel paket programından yararlanılmış- } \\
\text { tır. }\end{array}$ \\
\hline
\end{tabular}

Gönderilme Tarihi 21 Ocak 2020

Revizyon Tarihi 11 Mart 2020

Kabul Tarihi 16 Mart 2020

Makale Kategorisi: Araştırma Makalesi
Bulgular - Yapılan anket çalışması sonucunda, katılım bankası çalışanlarının; yaşları açısından anketin B bölümünde (faizsiz finans muhasebe standartlarının uygulanmasını zorlaştıracak nedenler), C bölümünde (faizsiz finans muhasebe standartlarının uygulanmasını kolaylaştırıcı nedenler) ve D bölümünde (faizsiz finans muhasebe standartlarının uygulanmasına yönelik düşünceler) yer alan ifadelere, bilgi düzeyleri ve çalıştıkları bankaların sermaye yapısı açısından ise anketin D bölümünde (faizsiz finans muhasebe standartlarının uygulanmasına yönelik düşünceler) yer alan ifadelere katılım düzeylerinde 0,05 anlamlılık düzeyinde anlamlı bir farklılık olduğu tespit edilmiştir. Araştırmanın sonuçlarına göre, Sivas ilinde faaliyet gösteren katılım bankası çalışanlarının \% 75 'inin faizsiz finans muhasebe standartları hakkında bilgi sahibi olduğu, faizsiz finans muhasebe standartları ile ilgili farkındalığın oluşmadığı, katılım bankalarının henüz böyle bir değişikliğe hazır olmadığı sonuçlarına ulaşılmıştır. Katılımclar, faizsiz finans muhasebe standartlarının uygulanmasında birçok yasal engel ortaya çıabileceğine de dikkat çekmişlerdir. Bununla birlikte katılımcılar, hükümetin faizsiz bankacılık ve faizsiz finansı geliştirici politikalar izlemesi, katılım bankalarının ve diğer faizsiz finans kuruluşlarının sayısının giderek artması gibi durumlardan dolayı faizsiz finans muhasebe standartlarının uygulanmasının kolaylaşabileceğini, bu noktada TCMB, BDDK, TÜRMOB, KGK, TKBB SPK gibi kurumların önemli rol oynayacağını vurgulamışlardır. Ayrıca katılımcılar tarafından, üniversiteler bünyesinde faizsiz bankacılık ve faizsiz finansla ilgili lisans, yüksek lisans ve doktora programlarının açılması, Kalkınma Planlarında faizsiz bankacılığın ve faizsiz finansın geliştirilmesine yer verilmesi durumunda faizsiz finans muhasebe standartlarının uygulanmasının ivme kazanacağını düşünülmektedir.

Tartışma - Faizsiz finans muhasebe standartlarının 1 Ocak 2020 veya sonrasında başlayan yıllık hesap dönemlerinde ihtiyari olarak uygulanabilecek olması, Türkiye'de yakın bir zamana kadar faaliyetlerine uygun finansal raporlama ve muhasebe çerçevesine sahip bulunmayan katılım bankaları açısından bir dönüm noktası olarak kabul edilebilir. Bu durum katılım bankaları için bir geçiş sürecidir ve geçiş süreçleri her zaman sancılıdır. Nitekim Sivas il merkezinde faaliyet gösteren katılım bankası çalışanlarının büyük bir çoğunluğu faizsiz finans muhasebe standartları hakkında bilgi sahibi olmakla birlikte, katılım bankalarının henüz böyle bir değişikliğe hazır olmadığı, faizsiz finans muhasebe standartlarının uygulanmasında bir takım sıkıntıların yaşanabileceği değerlendirilmektedir. Katılım bankalarının faaliyetlerini faizsiz finans yaklaşımı çerçevesinde raporlama imkânına kavuşmuş olmaları Türkiye' de faaliyet gösteren katılım bankaları açısından, bir takım sıkıntıların ortaya çıkması muhtemel olan, önemli bir süreçtir. Bu süreçte ortaya çıkması muhtemel sıkıntıların giderilmesi anlamında kamu otoritesi yanında özellikle akademik çevrelere önemli görevler düşmektedir.

\section{Önerilen Atıf/ Suggested Citation}

Şenel, S. A., Arslan, Ö. (2020). Katılım Bankası Çalışanlarının Faizsiz Finans Muhasebe Standartlarına Bakış Açılarının Analizi: Sivas İli Örneği, İşletme Araştırmaları Dergisi, 12 (2), 1394-1414.. 


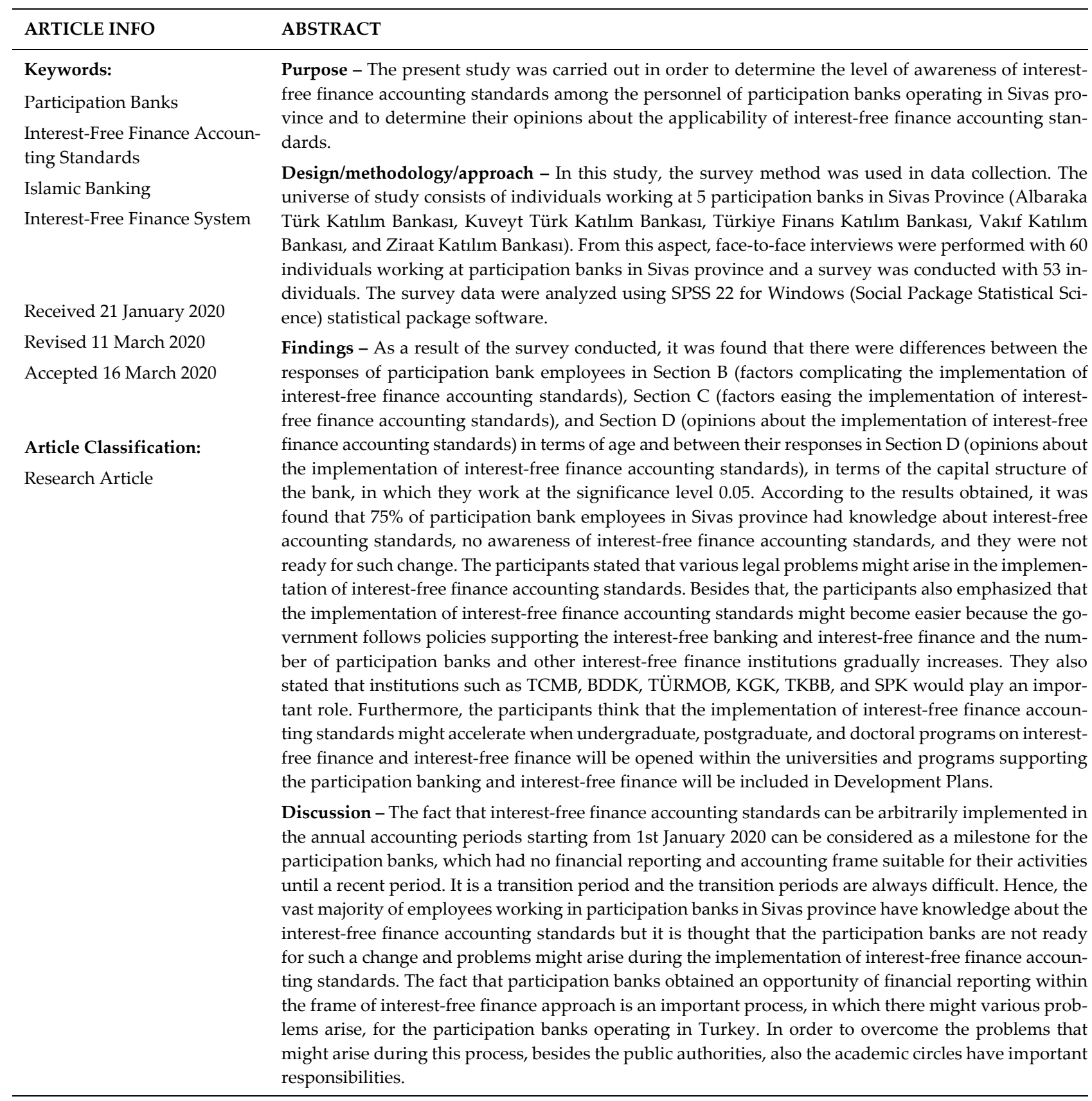

\section{Giriş}

Ekonomik olarak kalkınmanın temel ilkelerinden bir tanesi, çeşitli nedenlerle ekonomi dışında kalmış atıl fonların farklı enstrümanlar aracılığıyla, reel sektöre kanalize edilmesidir. Söz konusu atıl kaynak tutarı ne kadar çoğalırsa, ülke ekonomisinin gelişimi o kadar olumsuz etkilenecektir (Özulucan ve Deran, 2009:102). Fonların farklı enstrümanlar aracılığıyla, reel sektöre kanalize edilmesi finansal piyasalar aracılığı ile gerçekleşir. Finansal piyasalar, fon arz edenler (tasarruf fazlasına sahip birimler) ile fon talep edenlerin (tasarruf açı̆̆ı bulanan birimler) karşılaştığı, fon ve finansal varlıkların transferinin gerçekleştiği piyasalardır. Finansal piyasalarda birçok ürün ve sözleşmenin temelini teşkil eden faiz, İslam dininde yasaklanmıştır. Bununla birlikte İslam Dini Müslümanları İslam Hukuku'nu ihlal etmeden ekonomik faaliyetlere katılma noktasında teşvik etmektedir (Özdemir vd., 2019:1154).

Atıl kaynak tutarının çoğalmasının ülke ekonomisinin gelişimini olumsuz etkileyeceği gerçeği ve finansal piyasalarda birçok ürün ve sözleşmenin temelini teşkil eden faizin İslam dininde haram kılınmış olması ancak İslam Dininin Müslümanları İslam Hukuku'nu ihlal etmeden ekonomik faaliyetlere katılma noktasında teşvik etmesi Müslüman ülkelerinde ayrı bir finans sisteminin oluşumuna neden olmuştur (Ağkan, 2018:236). Bu durum, özellikle Müslümanların yoğun olarak yaşadığı ülkelerde faizsiz ve İslami esaslara uygun işlem yapan ve temelde kâr-zarar ortaklığı prensibiyle çalışan, İslami finans kuruluşlarının ve İslami bankaların ortaya 


\section{S. A. Şenel - Ö. Arslan 12/2 (2020) 1394-1414}

çımmasına yol açmıştır. İslami finans kuruluşları ve İslami bankalar, İslami esaslara uygun işlem yapmaları dolayısıyla diğer finans kuruluşlarından ayrılmaktadırlar.

Kamu Gözetimi Muhasebe ve Denetim Standartları Kurumu (KGK), Türkiye' de faaliyet gösteren katılım bankalarının faaliyetlerine uygun olarak finansal tablolarında gerçeğe ve ihtiyaca uygun bilgi sunmalarını sağlamak ve söz konusu kuruluşların finansal tablolarının hem kendi aralarında hem de benzer nitelikteki yabancı kuruluşlar ile karşılaştırılabilirliğini artırmak amacıyla, uluslararası düzeyde İslami Finansal Muhasebe Standartları yayınlayan tek kurum olan İslami Finansal Kuruluşlar Muhasebe ve Denetim Organizasyonu (Accounting and Auditing Organization for Islamic Financial Institutions (AAOIFI) tarafından yayımlanan muhasebe, denetim, etik ve yönetişim standartlarının Türkçeye çevrilerek mevzuatımıza kazandırılmasını teminen 27 Eylül 2017 tarihinde bir telif anlaşması imzalamıştır (www.kgk.gov.tr, Erişim Tarihi:17.12.2019). Öte yandan, Kamu Gözetimi Muhasebe ve Denetim Standartları Kurumu (KGK), 2019 Yılı Cumhurbaşkanlığı Yıllık Programı içerisinde yer alan 221 numaralı tedbir uyarınca faizsiz finans alanında yayımlanan uluslararası standartların mevzuatımıza kazandırılması görevini de üstlenmiştir (2019 Yılı Cumhurbaşkanlığı Yıllık Programı 2019:168). Bu bağlamda Kamu Gözetimi Muhasebe ve Denetim Standartları Kurumu (KGK) tarafından ülkemizdeki faizsiz finans sektörünün gelişimine katkı sağlamak, söz konusu sektöre özgü finansal işlemlerin kalitesini ve bu işlemler hakkında farkındalığı artırmak amacıyla faizsiz finans alanında yayımlanan uluslararası standartların mevzuatımıza kazandırılmasına yönelik çalışmalar yürütülmektedir.

Bu çalışmada, öncelikle Dünya genelinde İslami bankacılık, İslami finans kurumlarının ortaya çıkmasına bağlı olarak faizsiz finans muhasebe standartlarının oluşumu ve faizsiz finans muhasebe standartlarının Türkiye'deki gelişimi incelenmiştir. Daha sonra çalışmada Faizsiz Finans Muhasebe Standartlarını uygulayacak olan katılım bankası çalışanlarının faizsiz finans muhasebe standartlarına bakış açıları bağlamında analiz edilmiştir.

\section{2. İslami Finans ve Dünya Genelinde Katılım Bankacılığı}

Finansal piyasalarda birçok ürün ve sözleşmenin temelini teşkil eden faiz, Kur'an-1 Kerim'de birçok ayette kesin olarak yasaklanmıştır. Kur'an-1 Kerim'de faiz yasağının yer aldığı sûreler, ayet sayıları, nuzûl sıraları ve faiz yasağ ile ilgili ayetler aşağıda (Tablo 1) gösterilmektedir.

Tablo 1: Kur'an-1 Kerim'de Faiz Yasağının Yer Aldığı Sûreler

\begin{tabular}{clccl}
\hline Sıra & \multicolumn{1}{c}{ Sûre } & Ayet Sayısı & Nuzûl Sirasi & Faiz Yasağı ile İlgili Ayetler \\
\hline 30 & Rûm Sûresi & 60 & 84 & 39 \\
2 & Bakara Sûresi & 286 & 87 & $275,276,277,278,279$ \\
3 & Âl-i İmrân Sûresi & 200 & 89 & 130 \\
4 & Nisâ Sûresi & 176 & 92 & 160,161 \\
\hline
\end{tabular}

Kur'an-1 Kerim'de faiz yasağı ile ilgili ayetlerin Türkçe mealleri aşağıda verilmiştir1.

"İnsanların malları içinde artsın diye faizle her ne verirseniz, Allah katında artmaz. Ama Allah'ın hoşnutluğunu isteyerek her ne zekât verirseniz; işte bunu yapanlar sevaplarmı kat kat arttıranlardır." (Rûm Sûresi, 39).

"Faiz yiyenler, ancak şeytanın çarptığı kimsenin kalktığı gibi kalkarlar. Bu, onların, "Alı̧̧ veriş de faiz gibidir" demelerinden dolayıdır. Oysa Allah alı̧verişi helal, faizi haram kılmıştır. Bundan böyle kime Rabbinden bir öğüt gelir de (o öğ̈̈te uyarak) faizden vazgeçerse, artık önceden aldı̆̆̆ onun olur. Durumu da Allah'a kalmıştır. (Allah onu affeder.) Kim tekrar (faize) dönerse, işte onlar cehennemliklerdir. Orada ebedi kalacaklardır." (Bakara suresi, 275).

"Allah, faiz malını mahveder, sadakaları ise artırır (bereketlendirir). Allah hiçbir günahkâr nankörü sevmez." (Bakara suresi, 276).

"Şüphesiz iman edip salih ameller işleyen, namazı dosdoğru kılan ve zekâtı verenlerin mükâfatları Rableri katındadır. Onlara korku yoktur. Onlar mahzun da olmayacaklardır." (Bakara suresi, 277).

"Ey iman edenler! Allah'a karşı gelmekten sakının ve eğer gerçekten iman etmiş kimselerseniz, faizden geriye kalanı bırakın." (Bakara suresi, 278).

\footnotetext{
${ }^{1}$ Kur'an-1 Kerim ayetlerinin Türkçe mealleri, www.diyanet.gov.tr. adresinden alınmıştır. Erişim Tarihi:20.12.2019
} 


\section{S. A. Şenel - Ö. Arslan 12/2 (2020) 1394-1414}

"Ĕ̆er böyle yapmazsanız, Allah ve Rasûlüyle savaşa girdiğinizi bilin. Ĕ̆er tövbe edecek olursanız, anaparalarını sizindir. Böylece siz ne başkalarına haksızlık etmiş olursunuz, ne de başkaları size haksızlık etmiş olur." (Bakara suresi, 279).

"Ey iman edenler! Kat kat arttırılmış olarak faiz yemeyin. Allah'a karşı gelmekten sakının ki kurtuluşa eresiniz." (Âl-i İmrân Sûresi, 130).

"Yahudilerin yaptıkları zulüm ve birçok kimseyi Allah yolundan alıkoymaları, kendilerine yasaklanmış olduğu halde faiz almaları, insanların mallarımı haksız yere yemeleri sebebiyle önceden kendilerine helal kılınmış temiz ve hoş şeyleri onlara haram kıldık. İçlerinden inkâr edenlere de acı bir azap hazırladık." (Nisâ Sûresi, 160-161).

İslam dinine göre faizin haram kabul edilmesi nedeniyle Müslümanlar geçmişten bugüne birikimlerini kâr getiren faizsiz işlemlerde değerlendirmenin yollarını aramışlardır. Bu arayış, İslami finans kavramının ve İslami finans sisteminde yer alan İslami finans kurumlarının² ortaya çıkmasına yol açmıştır.

“İslami finans, genel olarak her türlü finansal faaliyet ve işlemlerin İslami kurallar çerçevesinde uygulandığı sistemdir. İslam dinine göre faizin haram kabul edilmesi nedeniyle modern finans anlayışına alternatif bir alan olarak değerlendirilen İslami finans son yıllardaki gelişmeler ışığında küresel finans piyasalarında alternatif bir alan olarak hızla gelişmiştir. Bu bağlamda İslami finansman yöntemlerinin tümü, faizli işlemlerin yasak olması ve İslam dininin iş ahlakının korunması ilkeleri üzerine dayanmaktadır" (SERPAM,2013:3).

Dünyada İslami Finans kurumları ile ilgili çalışmalar ilk olarak 1960'lı yıllarda başlamıştır. İslami ilkelerle uyumlu ilk İslami banka olarak, Mısır'ın Mit Ghamr adlı küçük bir köyünde bir ekonomist olan Ahmed ElNeccar tarafından 1963 yılında kurulan Mit Ghamr Tasarruf Bankası (Neccar İslam Bankası) görülmektedir. Faaliyeti üç yıl devam eden Mit Ghamr Tasarruf Bankası (Neccar İslam Bankası) 1967 yılında Mısır' da bulunan dokuz şubesi ile birlikte kapanmıştır (Odabaşı, 2011:87; Özdemir ve Aslan, 2017:12). İslami bankacilık ve finans kurumlarının sistemli olarak ortaya çıkması 1970'li yıllara dayanmaktadır. 1971 yılında Mısır'da devlet desteğiyle kurulan Nasr Sosyal Bankası ilk faizsiz ticari banka örneğidir. İlk tam teşekküllü İslami banka 1974 yılında Suudi Arabistan'ın Cidde kentinde İslam Kalkınma Bankası adıyla kurulmuştur. 1974 yılında Suudi Arabistan'ın Cidde kentinde kurulan ve Türkiye'nin de kurucu ülkeler arasında yer aldığı İslam Kalkınma Bankası, ilk tam teşekküllü İslami banka olarak kabul edilmektedir. 1975-1984 yılları arasında İslam Kalkınma Bankası'ndaki sermaye payını artıran Türkiye, kuruluşun en büyük ortaklardan birisi haline gelmiş, İslam Kalkınma Bankası Yönetim Kurulu'nda daimî üye bulundurma hakkını elde etmiştir. 1975 yılında kurulan Dubai İslam Bankası İslami ticari banka olarak faaliyete geçen ilk teşebbüstür ve İslam Kalkınma Bankasından sonra günümüze kadar devam eden en eski banka olma özelliğini taşımaktadır. İlerleyen yıllarda çoğunlukla Ortadoğu'da olmak üzere birçok İslam bankası (Mısır Faysal İslam Bankası 1977, Sudan Faysal İslam Bankası 1977, Ürdün Faysal İslam Bankası 1978, Ürdün İslam Bankası 1978, Bahreyn İslam Bankası 1979, Birleşik Arap Emirlikleri İslami Yatırım Şirketi 1979, Malezya İslam Bankası 1983) kurulmuştur. Batı'da bulunan Müslümanlara hizmet vermek ve İslam bankaları için acente fonksiyonu görmek amacıyla 1980 yılında Lüksemburg' da kurulan Uluslararası İslami Yatırım ve Kalkınma Bankası, Müslüman bir ülke haricinde kurulan ilk faizsiz bankadır (Ahmed,2006:44; Özulucan ve Özdemir, 2010:2, Odabaşı, 2011:87; Özdemir ve Aslan, 2017:12).

Kâr ve Zarar Paylaşımı Bankacılığı veya İslami Bankacılık olarak da bilinen, Katılım Bankacılığı İslam'ın fıkhı ilkelerine (Şer'i hükümler) dayanan ve İslam ekonomisi üzerinde şekillenen bir bankacılık sistemidir. Katılım Bankaları, varlık büyüklüğü bakımından İslami finans sisteminin önemli bir parçasıdır (Yatbaz, 2019:41). Öte yandan katılım bankaları, faizle ilgili olmayan, hemen hemen tüm bankacılık hizmetlerini farklı usullerle yapabildikleri için bir bakıma geleneksel bankaların alternatifi olurken, geleneksel bankaların yaptıkları ve faize dayanan kimi işlemleri de yapamadıkları için bir bakıma onları tamamlayan, finans sektörüne derinlik ve çeşitlilik kazandıran bir özellik taşırlar (Özulucan ve Özdemir, 2010:1).

İslami bankalar ve finansal kuruluşlar tarafından 26.02.1990 tarihinde Cezayir'de düzenlenen bir toplantıda, uluslararası standart ve uygulamalar ile İslami ilkelerle uyumlu ihtiyaçları göz önüne alarak İslami finansal kuruluşların faaliyetleriyle ilgili muhasebe, denetim, yönetişim ve etik standartlar hazırlamak ve geliştirmek amacıyla İslami Bankalar ve Finansal Kuruluşlar için Finansal Muhasebe Organizasyonu (Financial Accoun-

\footnotetext{
2 İslami finans kurumları; İslami Bankalar (Katılım Bankaları), İslami Pencereler, Tekafül (İslami Sigorta) Şirketleri, İslami Kolektif Yatırım Planları, İslami Yatırım Fonları, Mudaraba Şirketleri, İslami Morgage Şirketleri ve İslami Yatırım Bankaları olarak sayılmaktadir (Yatbaz 2019:42).
} 


\section{S. A. Şenel - Ö. Arslan 12/2 (2020) 1394-1414}

ting Organization for Islamic Banking and Financial Institution FAOIBFI) adıyla kâr amacı gütmeyen uluslararası ve özerk bir kurumun oluşturulması kararlaştııılmıştır. Söz konusu Kurum, İslam Kalkınma Bankası (Islamic Development Bank IDB) öncülüğünde Bahreyn'in Manama kentinde 27.03.1991 tarihinde resmen faaliyetlerine başlamıştır. Kurumun adı daha sonra İslami Finansal Kuruluşlar Muhasebe ve Denetim Organizasyonu (Accounting and Auditing Organization for Islamic Financial Institutions AAOIFI) olarak değiştirilmiştir (Yatbaz, 2019:169).

İslami Finansal Kuruluşlar Muhasebe ve Denetim Organizasyonu (Accounting and Auditing Organization for Islamic Financial Institutions AAOIFI) tarafından;

> 1 adet İslami Finansal Kuruluşlar için Finansal Raporlamaya Yönelik Kavramsal Çerçeve (Conceptual Framework for Financial Reporting by Islamic Financial Institutions),

> 26 adet Finansal Muhasebe Standardı (Financial Accounting Standards FAS),

$>5$ adet Denetim Standardı (Auditing Standards AS),

$>2$ adet Etik Standard1 (Ethics Standards ES),

> 7 adet Yönetişim Standardı (Governance Standards GS) ve

$>54$ adet Şer'i Standart (Shari'ah Standards SS)

olmak üzere Kavramsal Çerçeve dışında toplam 94 adet standart yayımlanmıştır (Iqbal, 2017:24; Ağkan, 2018:244; Yatbaz, 2019:170).

\section{Türkiye'de Katılım Bankacılığının Gelişimi}

“Türkiye'de katılım bankacılığı ile ilgili yaşanan ilk önemli gelişme, tasarruflarını faizsiz sisteme uygun olarak değerlendirmek isteyen vatandaşlara, küçük ve orta boy işletmelere hizmet vermek amacıyla kâr/zarar ortaklığı esaslarında işlem yapma yetkisine sahip olan Devlet Sanayi ve İşçi Yatııım Bankası'nın (DESİYAB) kurulmasıdır. Devlet Sanayi ve İşçi Yatırım Bankası (DESIYAB), 11.11.1975 tarihli 13 sayılı Kanun Hükmünde Kararname ${ }^{3}$ ile 1975 yılında kurulmuş ve bu yöndeki çalışmalarını 1978 yılına kadar sürdürmüştür4. Türkiye'de kâr/zarar ortaklığı esasına dayanan, faizsiz kredi ve finansman sağlamak üzere kurulan ilk mali kuruluş olan Devlet Sanayi ve İşçi Yatırım Bankası'nın (DESİYAB), Türkiye'ye katılım bankacılığı alanında önemli tecrübeler kazandırdığı ifade edilmektedir" (Ustaoğlu, 2014:24; Ersoy ve Süner, 2018:169).

“Türkiye' de katılım bankacılığı ile ilgili yaşanan bir başka önemli gelişme ise, 83/7506 sayılı Bakanlar Kurulu Karar1 ${ }^{5}$ ile 1983 yılında Özel Finans Kurumları'nın kurulmasıdır. Ardından Hazine ve Dış Ticaret Müsteşarlığı ve T.C. Merkez Bankası tarafından yayımlanan tebliğlerle sistemin ayrıntıları düzenlenmiştir. Daha sonra çıkarılan çeşitli tebliğ ve düzenlemeler sonucunda bu sistemin yasa ve mevzuat alt yapısı tamamlanmıştır ${ }^{\prime \prime}$ (Ustaoğlu, 2014:26).

Özel Finans Kurumları ile ilgili 83/7506 sayılı Bakanlar Kurulu Kararı'nın yürürlüğe girmesinden ve bu sistemin yasa ve mevzuat alt yapısının tamamlanmasından sonra Türkiye'nin ilk Özel Finans Kurumu olan Albaraka Türk 31 Ocak 1985 tarihinde faaliyete geçmiştir. Albaraka Türk'ün ardından Faisal Finans aynı yıl faaliyete başlayan ikinci kurum olmuştur. Bu kurumu 1989 yılında Kuveyt Türk, 1991 yılında Anadolu Finans, 1995 yılında İhlas Finans ve 1996 yılında Asya Finans izlemiştir (Ustaoğlu, 2014:38; Ersoy ve Süner, 2018:170; Sırım, 2013:189).

\footnotetext{
${ }^{3}$ 27.11.1975 tarihli 15425 sayılı Resmi Gazete. (11.11 1975 tarihli 13 sayılı Kanun Hükmünde Kararname, 14.11.1983 tarihli 18221 sayılı Resmi Gazete'de yayımlanan 4.11.1983 tarihli 165 sayılı Kanun Hükmünde Kararname (KHK/165) ile yürürlükten kaldırılmiştır).

${ }^{4} 1975$ yılında kurulan Devlet Sanayi İşçi Yatırım Bankası (DESIYAB) ilgili yönetim kurulunun 1978 yılında aldığı kararla faizli olarak çalışmaya başlamıştır (Ustaoğlu 2014:24).

5 19.12.1983 tarihli 18256 say1lı Resmi Gazete

${ }^{6}$ Hazine ve Dış Ticaret Müsteşarlığı Tebliği 25.02.1984 tarihli 18323 sayılı Resmi Gazete, T.C. Merkez Bankası Tebliği 21.03.1984 tarihli 18348 sayılı Resmi Gazete
} 


\section{S. A. Şenel - Ö. Arslan 12/2 (2020) 1394-1414}

Katılım bankacılığının temeli olarak kabul edilen Özel Finans Kurumları 1999 yılında 4491 sayılı Bankalar Kanununda Değişiklik Yapılmasına İlişkin Kanun ${ }^{7}$ ile 4389 Sayılı Bankalar Kanunu hükümlerine tabi olmuşlardır. Ancak, 2005 yılında yayımlanan 5411 sayılı Bankacılık Kanunu8 ile 4389 Sayılı Bankalar Kanunu ile ek ve değişiklikleri, yürürlükten kaldırılmış ve Özel Finans Kurumları (ÖFK) “Katılım Bankası” ibaresi ile 5411 sayılı Bankacilık Kanunu'nda kapsam altına alınmıştır.

Katılım bankası, özel cari ve katılma hesaplar yoluyla fon toplamak ve kredi kullandırmak esas olmak üzere faaliyet gösteren kuruluşlar ile yurt dışında kurulu bu nitelikteki kuruluşların Türkiye'deki şubeleri olarak tanımlanmaktadır (5411 sayılı Bankacılık Kanunu Mad:3).

Özel Finans Kurumları, 5411 sayılı Bankacılık Kanunu hükümleri uyarınca "banka" unvanını aldıktan sonra Bankacılık Düzenleme ve Denetleme Kurumu (BDDK) tarafından yürürlüğe konulan Yönetmelik ve Tebliğ hükümlerine tabi tutulmuştur. Ancak bu düzenlemelerin bazılarında, katılım bankalarına özgü işlem ve uygulamalarından kaynaklanan nedenlerden dolayı özel hükümlere yer verilmiştir. Ayrıca katılım bankaları, Bankacılık Düzenleme ve Denetleme Kurumu (BDDK) tarafından yayımlanan, mevduat bankaları ile kalkınma ve yatırım bankalarını kapsayan “Tekdüzen Hesap Planı ve İzahnamesi Hakkında Tebliğ” hükümlerine değil, yine aynı kurum tarafından yayımlanan "Katılım Bankalarınca Uygulanacak Tekdüzen Hesap Planı ve İzahnamesi Hakkında Teblï̆" hükümlerine tâbidirler9.

\section{Faizsiz Finans Muhasebe Standartları}

Faizsiz finans alanında yayımlanan uluslararası standartların mevzuatımıza kazandırılması görevini, daha önce de değinildiği gibi, 2019 Yılı Cumhurbaşkanlığı Yıllık Programı içerisinde yer alan 221 numaralı tedbir uyarınca Kamu Gözetimi Muhasebe ve Denetim Standartları Kurumu (KGK) üstlenmiştir (2019 Yılı Cumhurbaşkanlığ̣ Yıllık Programı 2019:168). Bu bağlamda Kamu Gözetimi Muhasebe ve Denetim Standartları Kurumu (KGK), İslami Finansal Kuruluşlar Muhasebe ve Denetim Organizasyonu (AAOIFI) tarafından faizsiz finans alanında yayımlanan standartların mevzuatımıza kazandırılması amacıyla çalışmalar yürütmektedir.

Kamu Gözetimi Muhasebe ve Denetim Standartları Kurumu (KGK) tarafından faizsiz finans standartları seti olarak;

> 1 adet Faizsiz Finans Kuruluşlarının Finansal Raporlamasına İlişkin Kavramsal Çerçeve (KÇ),

> 1 adet Faizsiz Finans Muhasebe Rehberi,

> 22 adet Faizsiz Finans Muhasebe Standardı (FFMS),

> 1 adet Faizsiz Finans Kuruluşlarının Bağımsız Denetimini Yürüten Denetçiler İçin Etik Kurallar ve

$>6$ adet Faizsiz Finans Denetim Standardı (FFDS) yayımlanmıştır (www.kgk.gov.tr).

Kamu Gözetimi Muhasebe ve Denetim Standartları Kurumu (KGK) tarafından yayımlanan faizsiz finans standartları seti aşağıda (Tablo 2) gösterilmektedir.

Tablo 2: Faizsiz Finans Standartları Seti

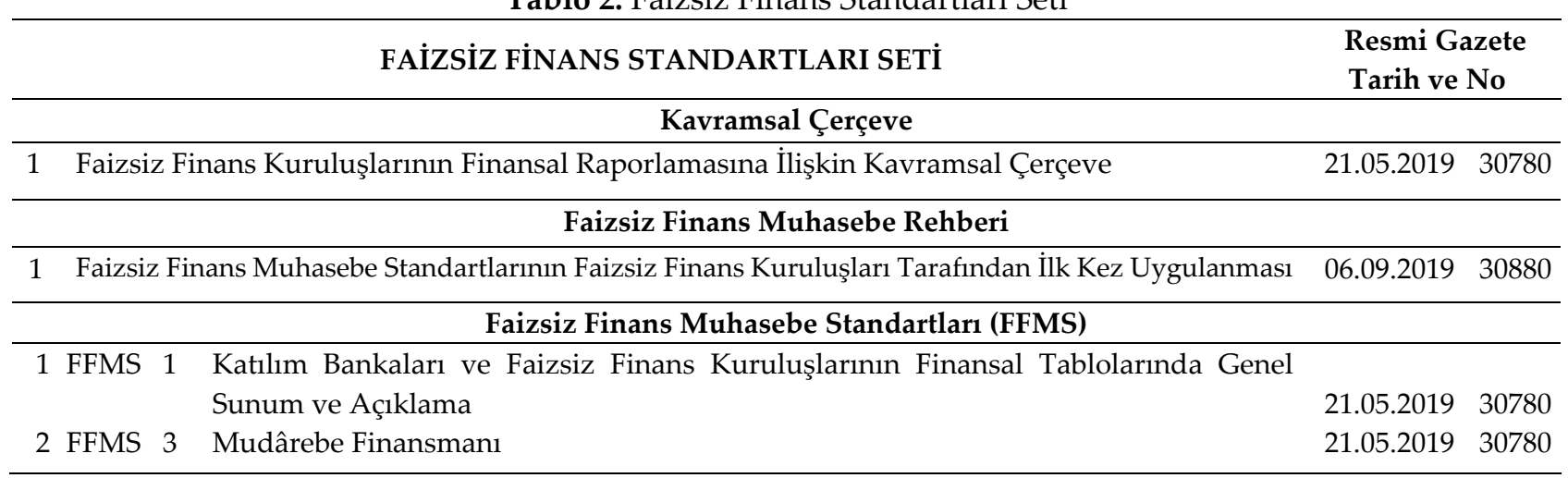

\footnotetext{
${ }^{7}$ 19.12.1999 tarihli 23911 say1l1 Resmi Gazete

${ }^{8}$ 01.11.2005 tarihli 25983 Mükerrer sayılı Resmi Gazete

${ }^{9}$ Her iki Tebliğ, 26.01.2007 tarihli 26415 Mükerrer sayılı Resmi Gazete'de yayımlanmıştır.
} 


\begin{tabular}{|c|c|c|c|c|}
\hline & FFMS 4 & Müşâreke Finansmanı & 21.05 .2019 & 30780 \\
\hline & FFMS 7 & Selem ve Alt Selem & 21.05.2019 & 30780 \\
\hline & FFMS 8 & İcâre ve İcâre Müntehiye Bittemlîk & 06.09.2019 & 30880 \\
\hline & FFMS 9 & Zekât & 21.05.2019 & 30780 \\
\hline & FFMS 10 & İstisnâ ve Alt İstisnâ & 21.05.2019 & 30780 \\
\hline & FFMS 14 & Yatırım Fonları & 06.09.2019 & 30880 \\
\hline 9 & FFMS 16 & Yabancı Para İşlemleri ve Yurtdışındaki İşletmeler & 06.09.2019 & 30880 \\
\hline 10 & FFMS 18 & Geleneksel Finans Kuruluşları Tarafından Sunulan Faizsiz Finans Hizmetleri & 06.09.2019 & 30880 \\
\hline 11 & FFMS 21 & Varlıkların Transferine İlişkin Açıklamalar & 06.09.2019 & 30880 \\
\hline 12 & FFMS 22 & Bölümlere Göre Raporlama & 06.09.2019 & 30880 \\
\hline 13 & FFMS 23 & Konsolidasyon & 06.09.2019 & 30880 \\
\hline & FFMS 24 & İştiraklerdeki Yatırımlar & 06.09.2019 & 30880 \\
\hline 15 & FFMS 26 & Gayrimenkul Yatırımları & 06.09.2019 & 30880 \\
\hline & FFMS 27 & Yatırım Hesapları & 06.09.2019 & 30880 \\
\hline 17 & FFMS 28 & Murâbaha ve Diğer Vadeli Satışlar & 21.05.2019 & 30780 \\
\hline 18 & FFMS 30 & Değer Düşüklüğü, Kredi Zararları ve Ekonomik Açıdan Dezavantajlı Taahhütler & 06.09.2019 & 30880 \\
\hline & FFMS 31 & Yatırım Vekâleti (EI-Vekâle Bi’1 İstithmar) & 20.11.2019 & 30954 \\
\hline 20 & FFMS 33 & Sukuk, Pay ve Benzeri Araçlara Yapılan Yatırımlar & 20.11.2019 & 30954 \\
\hline 21 & FFMS 34 & Sukuk Sahipleri İçin Finansal Raporlama & 20.11.2019 & 30954 \\
\hline & FFMS 35 & Risk Yedekleri & 20.11.2019 & 30954 \\
\hline \multicolumn{5}{|c|}{ Etik Kurallar } \\
\hline \multicolumn{3}{|c|}{1 Faizsiz Finans Kuruluşlarının Bağımsız Denetimini Yürüten Denetçiler İçin Etik Kurallar } & 14.12.2019 & 30978 \\
\hline \multicolumn{5}{|c|}{$\begin{array}{l}\text { Faizsiz Finans Denetim Standartları (FFDS) } \\
\end{array}$} \\
\hline & FFDS 1 & Bağımsız Denetimin Amacı ve İlkeleri & 14.12.2019 & 30978 \\
\hline & FFDS 2 & Bağımsız Denetçi Raporu & 14.12.2019 & 30978 \\
\hline 3 & FFDS 3 & Bağımsız Denetim Sözleşmesinin Şartları & 14.12.2019 & 30978 \\
\hline 4 & FFDS 4 & Bağımsız Denetçi Tarafından Fıkhî İlke ve Kurallara Uygunluğun Test Edilmesi & 14.12.2019 & 30978 \\
\hline \multirow{2}{*}{\multicolumn{2}{|c|}{6 FFDS 6}} & $\begin{array}{l}\text { Finansal Tabloların Bağımsız Denetiminde Bağımsız Denetçinin Hata ve Hileye } \\
\text { İlişkin Sorumlulukları }\end{array}$ & 14.12.2019 & 30978 \\
\hline & & $\begin{array}{l}\text { Fıkhî Denetim (Faizsiz Finans Kuruluşlarının Fıkhî İlke ve Kurallara Uygunluk } \\
\text { Sağlamasına Yönelik Güvence Denetimi) }\end{array}$ & 14.12.2019 & 30978 \\
\hline
\end{tabular}

Kaynak: www.kgk.gov.tr

Söz konusu Standartlardan;

FFMS 35: Risk Yedekleri 1 Ocak 2021 veya sonrasında başlayan yıllık hesap dönemlerinde,

> Diğer faizsiz finans muhasebe standartları 1 Ocak 2020 veya sonrasında başlayan yıllık hesap dönemlerinde,

> Faizsiz Finans Kuruluşlarının Bağımsız Denetimini Yürüten Denetçiler İçin Etik Kurallar 14 Aralık 2019 tarihinden itibaren,

> FFDS 6: Fıkhî Denetim (Faizsiz Finans Kuruluşlarının Fıkhî İlke ve Kurallara Uygunluk Sağlamasına Yönelik Güvence Denetimi) 01 Ocak 2021 tarihi ve sonrasında yürütülen denetimlerde,

> Diğer Faizsiz Finans Denetim Standartları 01 Ocak 2020 veya sonrasında başlayan yıllık hesap dönemlerinin denetimlerinde ihtiyari olarak uygulanabilecektir. İşletmelerin yayımlanan tüm standartları erken uygulamasina izin verilmektedir.

Ayrıca İslami Finans Kuruluşları Muhasebe ve Denetim Organizasyonu (AAOIFI) tarafından yayımlanan diğer faizsiz finans muhasebe standartlarının da mevzuatımıza kazandırılması çalışmaları kapsamında aşağıda sayılan standartlara ilişkin taslak metinler Kamu Gözetimi Muhasebe ve Denetim Standartları Kurumu (KGK) internet sitesinde kamuoyu görüşüne açılmıştır.

FFMS 12: Katılım Sigortacılığı Şirketlerinin Finansal Tablolarında Genel Sunum ve Açıklama

FFMS 13: Katılım Sigortacılığı Şirketlerinde Fazla veya Açığının Belirlenmesi ve Dağıtımına İlişkin Esasların Açılanması 


\section{S. A. Şenel - Ö. Arslan 12/2 (2020) 1394-1414}

FFMS 15: Katılım Sigortacılığ

FFMS 19: Katılım Sigortacılığı Şirketlerinde Katkılar

\section{Literatür Taraması}

Literatürde faizsiz finans muhasebe standartları ile ilgili doğrudan yapılmış amprik bir çalışma bulunmamaktadır. Fakat faizsiz finans muhasebe standartları ile bağlantılı çeşitli konuların katılım bankaları üzerindeki etkilerinin yer aldığı çalışmalar mevcuttur. Konu ile ilgili çalışmaların bazıları özet halinde sunulmuştur.

Hamim, Naziruddin ve Syed (2006), çalışmalarında, Malezya'da faaliyet gösteren İslami bankalar ile geleneksel bankaların etkinliklerini karşılaştırmışlardır. Araştırmada, İslami bankaların varlıkları, mevduatları ve finansman tabanlarının geleneksel bankalara nazaran hızla büyüdüğü ve İslami bankaların yerel bankalardan daha etkin olduğu tespit edilmişlerdir.

Sufian (2007) çalınmasında, Malezya İslami bankacılık sektörünün 2001-2005 arası verimliliğini incelemiştir. Araştırmada, Malezya İslami bankacılık sektöründe ölçek verimliliğinin teknik verimlilikten daha önemli olduğu ve yerel İslami bankaların yabancı İslami bankalara kıyasla daha yüksek teknik verimlilik gösterdiği sonuçlarına ulaşılmıştır.

Döndüren (2008) çalışmasında, Osmanlı devletinde faizsiz kredi sistemi ve ülkemizdeki faizsiz katılım bankalarının yapısı ve gelişim sürecini incelemiş, bankacılık sistemindeki faizsiz bankacılık uygulamalarının büyüme dönemlerinde ekonomiye istikrar getirdiği ve modern bankacılığın temellerinin atılmasında önemli rol oynadığı sonucuna ulaşmıştır.

Güney (2015) çalışmasında, İslami finansta şer'i yönetim uygulamaları üzerine yaptı̆̆ı çalışmasında İslami Finansal Kuruluşlar Muhasebe ve Denetim Organizasyonu (AAOIFI) yönetişim standartlarını ele almıştır. Çalışma sonucunda, yayınlanmış olan 5 yönetim standardının birbirini tamamlayıcı bir nitelik taşıdığı ve bu yüzden de bu standartlarının tamamının aynı anda uygulanması gerektiği belirtilmiştir.

Dinç (2016), "Katılım Bankaları Danışma Kurullarının Kurumsal Yönetim Olarak Değerlendirilmesi” isimli çalışmasında, İslami Finansal Kuruluşlar Muhasebe ve Denetim Organizasyonu (AAOIFI) yönetişim standartlarını irdelemiştir. Çalışma sonucunda Türkiye'de katılım bankalarının danışma kurullarına İslami Finansal Kuruluşlar Muhasebe ve Denetim Organizasyonu (AAOIFI) sisteminin uygulanabileceği belirtilmiş danışma kurulu örgütlemesi ile beraber, iç kontrol veya teftiş kurulu gibi bir örgütleme yapısı da tavsiye edilmiştir.

Sellami ve Tahari (2017) çalışmalarında İslami Finansal Kuruluşlar Muhasebe ve Denetim Organizasyonu (AAOIFI) tarafından yayınlanan standartların Orta Doğu ve Kuzey Afrika ülkelerindeki 38 İslami bankada 203 kriter ile uyumunu incelemişlerdir. Araştırma sonucunda standartlara uyma yönünden 203 kritere en yüksek varyansla Bahreyn, daha sonra sırasıyla Suriye, Ürdün, Katar, Yemen, Filistin ve Sudan gibi ülkeler gelmiştir.

Ağkan (2018), İslami Finansal Kuruluşlar Muhasebe ve Denetim Organizasyonu (AAOIFI) standartları ve Türkiye katılım bankalarında uygulanabilirliği konusunu teorik olarak ele aldığı çalışmasında, Türkiye'de katılım bankalarının Türkiye Muhasebe Standartlarını, Türkiye Finansal Raporlama Standartlarını ve Tek Düzen Hesap Planını zorunlu olarak, İslami Finansal Kuruluşlar Muhasebe ve Denetim Organizasyonu'nun (AAOIFI) yayımladığı faizsiz finans ilkelerini ise gönüllü olarak uyguladığını ortaya koymuştur.

Ersoy vd. (2018) çalışmalarında, İslami muhasebeyi geleneksel muhasebe çerçevesinde inceleyerek teorik bir çerçeve ortaya koymayı amaçlamışlardır. Araştırma sonucunda faizsiz finans muhasebesinin Malezya ve Bahreyn gibi faizsiz finans merkezi olan ülkelerde önemli ilerlemeler kaydettiğini, Türkiye'de ise faizsiz finans muhasebesinin gelişmesinin faizsiz finansın gelişmesine bağlı olduğunu belirlemişledir.

Yatbaz (2019) çalışmasında, İslami ilkelerle uyumlu muhasebe standartlarının Türkiye'de uygulanabilirliğini ortaya koymak amacıyla, Türkiye'de faaliyet gösteren beş adet katılım bankasının muhasebe ve finansal raporlama birimlerinde çalışmakta olan kişilere anket uygulamıştır. Ankete katılan kişilerin yaklaşık olarak \%58'inin İslami Finansal Kuruluşlar Muhasebe ve Denetim Organizasyonu (AAOIFI) muhasebe standartları ve dolayısıyla İslami muhasebe standartlarından haberdar olmadıkları tespit edilmiştir. Araştırmada, İslami muhasebe standartlarının Türkiye' de uygulanmak istenmesi durumunda, katılımcılar tarafından faizsiz bankacılık ve finans kesiminde yeterli talebin oluşmamasının en zorlaştırıcı etken, katılım bankalarının ve diğer faizsiz finans kuruluşlarının sayısının giderek artmasının ise en kolaylaştırıcı etken olduğu tespit edilmiştir. 


\section{S. A. Şenel - Ö. Arslan 12/2 (2020) 1394-1414}

Kartal ve Ay (2019), “Faizsiz Finans Kuruluşları Açısından Bir Dönüm Noktası: Faizsiz Finans Muhasebe Standartları (FFMS) Üzerine Bir İnceleme" adlı çalışmasında faizsiz finans muhasebe standartlarının kavramsal çerçevesini çizmiştir. Araştırmada, faizsiz finans muhasebe standartlarına ilişkin yapılan düzenlemelerin getirdiği uygulamaların Türk Bankacılık Sektörü ve Türk Katılım Bankacılığı üzerinde olumsuz gelişmelere sebebiyet vermemesi için Bankacilık Düzenleme ve Denetleme Kurumu (BDDK), Kamu Gözetimi Muhasebe ve Denetim Standartları Kurumu (KGK) ve Türkiye Katılım Bankaları Birliği'nin (TKBB) süreci takip etmeleri ve olumsuz etkilerin görülmesi halinde gerekli tedbirleri ivedilikle almaları gerekliliği vurgulanmıştır.

\section{Katılım Bankası Çalışanları Üzerine Bir Uygulama}

Bu çalışmada, araştırmanın amacına uygun olarak hazırlanan anket, Sivas il merkezinde faaliyet gösteren katılım bankası çalışanlarına uygulanmıştır.

\section{1. Çalışmanın Amacı ve Önemi}

Türkiye'de faizsiz finans muhasebe standartlarının 2020 yılı itibarıyla yürürlüğe girmesi ile katılım bankaları faaliyetlerini faizsiz finans yaklaşımı çerçevesinde raporlama imkânına kavuşmuştur. Bu durum katılım bankaları açısından bir dönüm noktası olarak kabul edilebilir.

Sivas il merkezinde faaliyet gösteren katılım bankası çalışanlarının faizsiz finans muhasebe standartlarına yönelik farkındalık düzeylerini belirlemek ve düşüncelerini tespit etmek amacıyla yapılan bu çalışmada Sivas il merkezinde faaliyet gösteren katılım bankası çalışanlarının faizsiz finans muhasebe standartlarına bakış açıları analiz edilmiştir. Kartal (2018:187) tarafından yapılan bir çalışmada Türkiye'de faizsiz bankacılıkla ilgili tezlerin sayıca az olduğu ve bu nedenle yeni çalışmaların yapılmasına ihtiyaç bulunduğu değerlendirilmektedir. Çalışmanın bu anlamda önemli olduğu ve ilgili literatüre önemli bir katkı sağlayacağı düşünülmektedir.

\subsection{Araştırmanın Evreni ve Örneklemi}

Türkiye Katılım Bankaları Birliği (TKBB) verilerine göre Türkiye' de 6 adet katılım bankası faaliyet göstermektedir. Toplam şube sayısı ise 1.171 adettir (Türkiye Katılım Bankaları Birliği, www.tkbb.org.tr, Erişim Tarihi: 20.12.2019). Türkiye'de faaliyet gösteren katılım bankaları ve şube sayıları aşağıda (Tablo 3) gösterilmektedir.

Tablo 3: Türkiye' de Faaliyet Gösteren Katılım Bankaları ve Şube Sayıları

\begin{tabular}{lc}
\hline \multicolumn{1}{c}{ Katılım Bankaları } & Şube Sayıları \\
\hline Albaraka Türk Katılım Bankası & 232 \\
Türkiye Emlak Katılım Bankası & 7 \\
Kuveyt Türk Katılım Bankası & 428 \\
Türkiye Finans Katılım Bankası & 310 \\
Vakıf Katılım Bankası & 101 \\
Ziraat Katılım Bankası & 93 \\
\hline TOPLAM & $\mathbf{1 . 1 7 1}$ \\
\hline
\end{tabular}

Kaynak: Türkiye Katılım Bankaları Birliği, www.tkbb.org.tr, Erişim Tarihi: 20.12.2019

Sivas'ta, Türkiye Emlak Katılım Bankası hariç diğer 5 katılım bankası faaliyet göstermektedir. Sivas'ta faaliyet gösteren 5 katılım bankasından Kuveyt Türk Katılım Bankası ve Türkiye Finans Katılım Bankasının 2 şubesi vardır (Türkiye Katılım Bankaları Birliği, www.tkbb.org.tr, Erişim Tarihi:20.12.2019). Sivas'ta faaliyet gösteren katılım bankaları aşağıda (Tablo 4) gösterilmiştir.

Tablo 4: Sivas'ta Faaliyet Gösteren Katılım Bankaları

\begin{tabular}{|c|c|c|}
\hline Banka Adı & ìl / İlçe & Açılış Yılı \\
\hline \multicolumn{3}{|c|}{ Albaraka Türk Katılım Bankası } \\
\hline Sivas Şubesi & Sivas / Merkez & 2006 \\
\hline \multicolumn{3}{|c|}{ Kuveyt Türk Katılım Bankası } \\
\hline Sivas Şubesi & Sivas / Merkez & 1997 \\
\hline Kızılırmak Şubesi & Sivas / Merkez & 2012 \\
\hline \multicolumn{3}{|c|}{ Türkiye Finans Katılım Bankası } \\
\hline Sivas Şubesi & Sivas / Merkez & 2002 \\
\hline Kızılırmak Şubesi & Sivas / Merkez & 2013 \\
\hline \multicolumn{3}{|l|}{ Vakıf Katılım Bankası } \\
\hline Sivas Şubesi & Sivas / Merkez & 2017 \\
\hline \multicolumn{3}{|l|}{ Ziraat Katılım Bankası } \\
\hline Sivas Şubesi & Sivas / Merkez & 2016 \\
\hline
\end{tabular}

Kaynak: Türkiye Katılım Bankaları Birliği, www.tkbb.org.tr, Erişim Tarihi:20.12.2019 


\section{S. A. Şenel - Ö. Arslan 12/2 (2020) 1394-1414}

$\mathrm{Bu}$ araştırmanın evrenini Sivas il merkezinde faaliyet gösteren 5 katılım bankasında çalışan kişiler oluşturmaktadır. Söz konusu bankaların şubelerinde çalışan toplam 60 personel olduğu görüşmelerde tespit edilmiştir. Araştırma evreninin bilindiği durumlarda, seçilecek örneklemin büyüklüğü belirlenirken aşağıdaki formülden yararlanılabilmektedir: (Salant ve Dillman, 1994:55)

$$
\frac{N \cdot t^{2} \cdot p \cdot q}{(N-1) \cdot d^{2}+t^{2} \cdot p \cdot q}
$$

Formülde,

$\mathrm{N}=$ Evrendeki birey sayısı

$\mathrm{N}=$ Örnekleme alınacak birey sayısı

P = İncelenecek olayın görülüşs sıklığı (gerçekleşme olasılığı)

$\mathrm{Q}=$ İncelenecek olayın görülmeyiş sıklığı (gerçekleşmeme olasılı̆̆ı)

$\mathrm{T}=$ Belirli bir anlamlılık düzeyinde, $\mathrm{t}$ tablosuna göre bulunan teorik değer

$\mathrm{d}$ = Olayın görülüşs sıklığına göre yapılmak istenen + sapma olarak simgelenmiştir.

$$
\frac{60 \cdot 1,96^{2} \cdot 0,50 \cdot 0,50}{(60-1) \cdot 0,05^{2}+1,96^{2} \cdot 0,50 \cdot 0,50}=52,01
$$

Formüle göre, \% 95 güven aralığında \% 5 hata payı ile örneklem büyüklüğü 52 olarak hesaplanmıştır. Çalışma kapsamında Sivas ili merkez ilçede faaliyet gösteren katılım bankalarındaki 60 çalışanın tümüyle yüz yüze görüşülerek 53 çalışana anket uygulanmıştır. Örneklem araştırma evrenini temsil edecek niteliktedir.

\subsection{Veri Toplama Aracı ve Verilerin Toplanması}

Araştırmada veri toplama aracı olarak anket formu kullanılmıştır. Bu çerçevede araştırmanın amacına hizmet edecek şekilde literatürde yer alan konu ile ilgili çalışmalardan yararlanılarak (Eskici, 2007; Yatbaz, 2019) bir anket formu hazırlanmıştır. Anket formunda yer alan soruların kolay anlaşılabilir ve odaklı sorular olmasına, soruların herhangi bir yönlendirme içermemesine dikkat edilerek mantıklı bir biçimde düzenlenmesi yoluna gidilmiştir. Anket formu A, B, C, D ve E olmak üzere beş bölümden oluşmaktadır.

Anketin A bölümünde araştırmaya katılan katılım bankası çalışanlarının; cinsiyet, yaş, eğitim durumu, mesleki tecrübe ve faizsiz finans muhasebe standartlarına yönelik farkındalık düzeylerinin belirlenmesine ilişkin 7 soru yer almaktadır. Anketin B, C ve D bölümlerinde araştırmaya katılan katılım bankası çalışanlarının faizsiz finans muhasebe standartlarına yönelik görüşlerini belirleyici nitelikte 5'li likert formunda toplam 33 ifade yer almaktadır. Toplam 33 ifadenin 11 tanesi B bölümündedir ve faizsiz finans muhasebe standartlarının uygulanmasını zorlaştıracak nedenlere yöneliktir. $C$ bölümünde, faizsiz finans muhasebe standartlarının uygulanmasını kolaylaştırıı nedenlere yönelik 9 ifade yer almaktadır. D bölümünde yer alan 13 ifade, katılım bankası çalışanlarının faizsiz finans muhasebe standartlarının uygulanmasına yönelik düşüncelerinin belirlenmesi amacına yöneliktir. E bölümünde ise, faizsiz finans muhasebe standartlarının uygulanmasında kişi veya kurumların önem derecesini belirlemeye yönelik 10 ifade yer almaktadır.

\subsection{Araştırmada Kullanılan İstatistiksel Teknikler}

Anket verilerinin analizinde, SPSS 22 for Windows (Social Package Statiscal Science) istatistiksel paket programından yararlanılmıştır. Örnekleme ait ham verilerin çözümlenmesi betimsel istatistik yöntem ve teknikleri kullanılarak yapılmıştır. Çözümlenen verilerin tablolar halinde ifade edilmesinde demografik yapı ve araştırma amacına yönelik hazırlanmış ifadelere ait cevapların frekans (f) ve yüzde (\%) değerleri dikkate alınmıştır. Verilerin normal dağılım gösterip göstermediği test edilmiştir. Yapılan test sonucunda verilerin normal dağılmadığı görülmüştür.

Bağımsız iki grup ortalamasının t-testi ile karşılaştırılabilmesi için grupların alınmış oldukları kitle dağılımlarının normal olması, grup varyanslarının homojen olması ve gözlemlerin bağımsız olması varsayımlarının yerine gelmesi gerekir (Mendeş 2012:155). Normal dağılıma uygun verilere non-parametrik test uygulaması pek hatalı sayılmazken, normal dışı dağılım gösteren verilere parametrik test uygulaması daha çok sakıncalıdır (Karagöz 2010:19). Veriler normal dağılım göstermediğinden hipotezleri test etmek için non-parametrik testlerden ikili gruplar için Mann Whitney U testi üç ve daha fazla olan gruplar için ise Kruskal Wallis testi yapılmıştır. 


\section{S. A. Şenel - Ö. Arslan 12/2 (2020) 1394-1414}

Dağılımın normal olmadığı veya dağılımın şeklinin bilinmediği durumda iki örneklemli $t$ testine karşılık parametrik olmayan Mann Whitney U testi davranış bilimlerinde en sık kullanılan testlerden biridir. Mann Whitney $U$ testi bağımsız örnekler için uygulanan $t$-testinin parametrik olmayan (non-parametrik) alternatifidir. $t$ testinde olduğu gibi iki grup ortalamalarının karşılaştırılması yerine, Mann Whitney U testi, grupların medyanlarını karşılaştırır. Sürekli değişkenlerin, iki grup içerisinde değerlerini sıralı hale dönüştürür. Değerler sıralı hale dönüştürüldüğü için değerlerin asıl dağılımları önemli değildir (Bindak, 2014:7; Karagöz, 2017:557). Kruskal Wallis testi normal dağılım göstermeyen gruplarda ikiden fazla sayıda grubun ortalamaları arasındaki farklılığın anlamlılığını test amacıyla kullanılan One Way ANOVA'nın non-parametrik karşılığıdır. Güvenirlilik analizi, ölçmeye çalışılan araçların, güvenirliğini değerlendirmek amacıyla geliştirilmiş bir yöntemdir (Karagöz, 2010:19).

Cronbach's Alpha katsayısı güvenirliliği ölçmede kullanılan yöntemlerden biridir. Bu yöntem, ölçekte yer alan sorunun homojen bir yapıyı açıklamak üzere bir bütün oluşturup oluşturmadıklarını araştırır (Karagöz, 2017:557). Katılım bankası çalışanlarına uygulanan anket formunun geçerlilik ve güvenirliğinin istenen değerlerde olup olmadığını Cronbach's Alpha katsayısı ile tespit edilmeye çalışılmış ve analiz sonucu Tablo 5'de gösterilmiştir.

Tablo 5: Cronbach's Alpha İç Tutarlılık Katsayısı

\begin{tabular}{lccc} 
& Madde Sayısı & İç Tutarlılık Katsayısı & Güvenirlik Durumu \\
\cline { 2 - 4 } Anket Formu & 43 & 0,917 & Yüksek Derecede Güvenilir \\
\hline
\end{tabular}

Tablo 5'de görüldüğ̈̈ gibi Cronbach's Alpha iç tutarlılık katsayısı 0,917 olarak hesaplanmıştır. Bu sonuca göre söz konusu 43 ifadenin bir bütün olarak, ölçmek istenen olguyu ölçmede "yüksek derecede güvenilir" olduğu söylenebilir.

\section{Bulgular ve Yorum}

Araştırmanın bu aşamasında, Sivas il merkezinde faaliyet gösteren katılım bankası çalışanlarına anket formunun uygulanmasıyla elde edilen veriler, belirtilen istatiksel tekniklerle analiz edilmiş ve analiz sonuçları tablolar halinde sunularak yorumlanmaya çalışılmıştır.

\subsection{Katılım Bankası Çalışanlarının Demografik Özellikleri}

Katılım bankası çalışanlarının anketin A bölümündeki sorulara verdikleri cevaplarının istatistik sonuçları Tablo 6' da yer almaktadir.

Tablo 6: Katılım Bankası Çalışanlarının Demografik Özelliklerine Ait İstatistiki Sonuçlar

\begin{tabular}{|c|c|c|c|c|c|}
\hline \multicolumn{3}{|c|}{ Yaşınız? } & \multicolumn{3}{|c|}{ Eğitim Durumunuz? } \\
\hline Yaş Aralı̆̆ & Frekans (f) & Yüzde (\%) & Eğitim Seviyesi & Frekans (f) & Yüzde (\%) \\
\hline 23-34 yaş & 32 & 60,4 & Ön lisans & 5 & 9,4 \\
\hline $35-44$ yaş & 21 & 39,6 & Lisans & 44 & 83,1 \\
\hline \multirow[t]{2}{*}{ TOPLAM } & 53 & 100,0 & Yüksek Lisans & 4 & 7,5 \\
\hline & & & TOPLAM & 53 & 100,0 \\
\hline \multicolumn{3}{|c|}{ Cinsiyetiniz? } & \multicolumn{3}{|c|}{ Kaç Yıldır Bu İşi Yapıyorsunuz? } \\
\hline Cinsiyet & Frekans (f) & Yüzde (\%) & Mesleki Deneyim & Frekans (f) & Yüzde (\%) \\
\hline Erkek & 40 & 75,5 & $1-5$ yil & 21 & 39,6 \\
\hline Kadın & 13 & 24,5 & $6-9$ yil & 16 & 30,2 \\
\hline \multirow[t]{2}{*}{ TOPLAM } & 53 & 100,0 & $10-15$ y1l & 16 & 30,2 \\
\hline & & & TOPLAM & 53 & 100,0 \\
\hline
\end{tabular}

\section{Çalıştığınız Kurumun Sahiplik Durumu? KG Tarafından Yayınlanan Faizsiz Finans}

Muhasebe Standartlarından Haberdar misınız?

\begin{tabular}{|c|c|c|c|c|c|}
\hline \\
\hline Sahiplik Durumu & Frekans (f) & Yüzde (\%) & Bilgi Düzeyi & Frekans (f) & Yüzde (\%) \\
\hline Kamu Bankası & 23 & 43,3 & Haberdarım & 40 & 75,5 \\
\hline Özel Banka & 30 & 56,7 & Haberdar Değilim & 13 & 24,5 \\
\hline TOPLAM & 53 & 100,0 & TOPLAM & 53 & 100,0 \\
\hline \multicolumn{6}{|c|}{ Türkiye'de Faizsiz Finans Muhasebe Standartlarının Uygulanması Fikrine Nasıl Bakıyorsunuz? } \\
\hline \multicolumn{2}{|c|}{ Görüsşleri } & \multicolumn{2}{|c|}{ Frekans (f) } & \multicolumn{2}{|c|}{ Yüzde $(\%)$} \\
\hline \multicolumn{2}{|l|}{ Çok Olumlu } & \multicolumn{2}{|c|}{14} & \multicolumn{2}{|c|}{26,4} \\
\hline \multicolumn{2}{|l|}{ Olumlu } & \multicolumn{2}{|r|}{32} & \multicolumn{2}{|c|}{60,4} \\
\hline \multicolumn{2}{|l|}{ Ne olumlu / ne olumsuz } & \multicolumn{2}{|r|}{7} & \multicolumn{2}{|c|}{13,2} \\
\hline \multicolumn{2}{|l|}{ TOPLAM } & \multicolumn{2}{|r|}{53} & \multicolumn{2}{|c|}{100,0} \\
\hline
\end{tabular}




\section{S. A. Şenel - Ö. Arslan 12/2 (2020) 1394-1414}

Tablo 6'da görüldüğü gibi ankete katılan çalışanların öne çıkan demografik özellikleri aşağıdaki gibi özetlenebilir:

> Katılım bankası çalışanlarının yarıdan fazlasının 35 yaşın altında olduğu görülmektedir. 23-34 yaş aralığında olan çalışanların oranı \%60,4 iken \%39,6'sı ise 35-44 yaş aralığındadır.

> Katılım bankası çalışanlarının büyük bir kısmı lisans mezunu iken, yüksek lisans mezunu olan çalışanlar, ön lisans mezunu olanlara göre daha az sayıdadır. Katılım bankası çalışanlarının \%9,4'ü ön lisans, \%83,1'i lisans ve $\% 7,5^{\prime} \mathrm{i}$ ise yüksek lisans mezunu olduğu görülmektedir.

> Katılım bankalarında çalışanlarının ağırlıklı olarak erkek olduğu görülmektedir. Katılım bankası çalışanlarının \%75,5'i erkek; \%24,5'i kadın personeldir.

> Katılım bankası çalışanları arasında çalışma süreleri açısından önemli bir farklılık görülmemektedir. Katılım bankası çalışanlarının \%39,6'sı 1-5 yıl; \%30,2'si 6-9 yıl ve geriye kalan \%30,2'si ise 10-15 yıl arasında deneyime sahip oldukları tespit edilmiştir.

> Katılım bankası çalışanlarının çalıştıkları bankaların sahiplik durumu incelendiğinde çalışanların \%43,4'ünün Kamu, \%56,7'sini ise Özel bankada çalıştığı görülmektedir.

> Katılım bankası çalışanlarının büyük bir kısmının Faizsiz Finans Muhasebe Standartlarından haberdar olduğu görülmektedir. Katılım bankası çalışanlarının \%75,5'i Faizsiz Finans Muhasebe Standartlarından haberdar olduğunu belirtirken, \%24,5'i ise haberdar olmadığını belirtmişlerdir.

> Faizsiz finans muhasebe standartlarının Türkiye'de uygulanmasının "çok olumlu" ve "olumlu" olacağ1 görüşüne katılan Katılım bankası çalışanlarının oranı \%86,8'dir. Faizsiz finans muhasebe standartlarının Türkiye'de uygulanması hakkında katılım bankası çalışanlarının 26,4'ü çok olumlu, \%60,4'ü olumlu ve $\% 13,2$ 'si ise ne olumlu/ne olumsuz yönünde görüş bildirmişlerdir.

\subsection{Katılım Bankası Çalışanlarının Diğer Bölümlerdeki İfadelere Yönelik Katılım Düzeylerinin Belirlenmesine İlişkin Bulgular}

Katılım bankası çalışanlarının, anketin B, C ve D bölümlerinde bulunan "Kesinlikle Katılıyorum, Katılıyorum, Kararsızım, Katılmıyorum ve Kesinlikle Katılmıyorum", E bölümünde yer alan "Çok Önemli, Önemli, Fikrim Yok, Önemli Değil ve Hiç Önemli Değil" nitelendirmelerine hangi düzeyde katıldığı yapılan bir sınıflama ölçeği ile belirlenmiştir. Sınıflama ölçeğinin oluşturulmasında [Aralık Genişliği (a) = Dizi Genişliği $\div$ Yapılacak Grup Sayısı] ölçek aralık formülü kullanılmış ve Aralık Geniş̧liği (a) $=4 \div 5=0,80$ bulunmuştur. Buna göre oluşturulan ölçekte; nitelik düzeyi ve puan değerleri ile değer aralıkları Tablo 7'de gösterilmiştir (Tekin, 1987:262).

Tablo 7: Anket Maddelerinin Puan Aralıkları

\begin{tabular}{lcclcc}
\hline \multicolumn{1}{c}{ Nitelik Düzeyi } & Puan Aralığı & Değer Aralıkları & Nitelik Düzeyi & Puan Aralığı & Değer Aralıkları \\
\hline Kesinlikle Katılıyorum & 5 & $4,20-5,00$ & Çok Önemli & 5 & $4,20-5,00$ \\
Katılıyorum & 4 & $3,40-4,19$ & Önemli & 4 & $3,40-4,19$ \\
Kararsızım & 3 & $2,60-3,39$ & Fikrim Yok & 3 & $2,60-3,39$ \\
Katılmıyorum & 2 & $1,80-2,59$ & Önemli Değil & 2 & $1,80-2,59$ \\
Kesinlikle Katılmıyorum & 1 & $1,00-1,79$ & Hiç Önemli Değil & 1 & $1,00-1,79$ \\
\hline
\end{tabular}

Anketin B bölümünde "faizsiz finans muhasebe standartlarının uygulanmasını zorlaştıracak nedenler" ile ilgili 11 ifade yer almaktadır. Katılım bankası çalışanlarının bu ifadelere verdikleri cevaplara ilişkin olarak bulunan, aritmetik ortalama $(\overline{\boldsymbol{x}})$ ve standart sapma (ss) değerleri ve bu değerlerin karşılı̆̆ olan katılım düzeyleri Tablo 8 'de gösterilmiştir. 
Tablo 8: Katılım Bankası Çalışanlarının FFM Standartlarının Uygulanmasını Zorlaştırııı Nedenlere Yönelik İfadelere Katılım Düzeyleri

\begin{tabular}{|c|c|c|c|c|c|}
\hline \multicolumn{6}{|c|}{ Faizsiz Finans Muhasebe Standartlarının Uygulanmasını Zorlaştıracak Nedenler } \\
\hline No & İfadeler & $\mathbf{n}$ & $\overline{\boldsymbol{x}}$ & ss & Katılım Düzeyi \\
\hline 1 & Mevcut standartların yeterli görülmesi & 53 & 3,92 & 1,09 & Katıliyorum \\
\hline 2 & Değişikliği gerektirecek yeteri kadar mevcut işlem bulunmaması & 53 & 3,74 & 0,84 & Katıliyorum \\
\hline 3 & Henüz yeterli bir farkındalığın oluşmamış olması & 53 & 4,04 & 0,73 & Katıliyorum \\
\hline 4 & Yasal engellerin bulunması ve aşıllamayacağı düşüncesi & 53 & 3,74 & 1,00 & Katıliyorum \\
\hline 5 & Mevcut standartların ihtiyacı karşıladığı düşüncesi & 53 & 3,81 & 0,94 & Katıliyorum \\
\hline 6 & Faizsiz bankaların henüz böyle bir değişikliğe hazır olmaması & 53 & 3,83 & 0,85 & Katıllyorum \\
\hline 7 & Bu alanda uzman muhasebeci ve denetçi sıkıntısı & 53 & 3,87 & 0,90 & um \\
\hline 8 & Faizsiz & 53 & 4,13 & 0,65 & rum \\
\hline 9 & Faizsiz finans muhasebe standartlarının zorlayıcı olmaması & 53 & 3,75 & 0,85 & Katıliyorum \\
\hline \multirow[t]{2}{*}{10} & İslami Finansal Kuruluşlar Muhasebe ve Denetim Organizasyonu tarafından & & & & \\
\hline & & 53 & 3,89 & 0,78 & Katıliyorum \\
\hline 11 & Uygulamada çift başlılığın ortaya çıkacağı düşüncesi & 53 & 3,87 & 0,76 & Katıllyorum \\
\hline \multicolumn{2}{|r|}{ ORTALAMA } & 53 & 3,87 & 0,85 & Katılıyorum \\
\hline
\end{tabular}

Tablo 8' de katılım bankası çalışanlarının anketin B bölümünde yer alan "faizsiz finans muhasebe standartlarının uygulanmasını zorlaştıracak nedenler" ile ilgili ifadelerin tamamına katılım düzeylerinin "katılıyorum" yönünde olduğu görülmektedir. Bu sonucu, katılım bankası çalışanlarının, faizsiz finans muhasebe standartlarının uygulanmasında katılım bankalarının zorlanacağı yönde genel bir kanıya sahip oldukları şeklinde yorumlayabiliriz.

Anketin C bölümünde "faizsiz finans muhasebe standartlarının uygulanmasını kolaylaştırıcı nedenler" ile ilgili 9 ifade yer almaktadır. Katılım bankası çalışanlarının bu ifadelere verdikleri cevaplara ilişkin olarak bulunan, aritmetik ortalama $(\overline{\boldsymbol{x}})$ ve standart sapma (ss) değerleri ve bu değerlerin karşılığı olan katılım düzeyleri Tablo 9 'da gösterilmiştir.

Tablo 9: Katılım Bankası Çalışanlarının FFM Standartlarının Uygulanmasını Kolaylaştırıcı Nedenlere Yönelik İfadelere Katılım Düzeyleri

\begin{tabular}{|c|c|c|c|c|c|}
\hline \multicolumn{6}{|c|}{ Faizsiz Finans Muhasebe Standartlarının Uygulanmasını Kolaylaştırıcı Nedenler } \\
\hline No & İfadeler & $\mathbf{n}$ & $\bar{x}$ & ss & Katılım Düzeyi \\
\hline 1 & $\begin{array}{l}\text { Türkiye nüfusunun büyük çoğunluğunun kendini Müslüman olarak tanımlıyor ol- } \\
\text { ması }\end{array}$ & 53 & 3,81 & 0,96 & Katıliyorum \\
\hline 2 & Hükümetin faizsiz bankacılık ve finansı geliştirici politikalar izlemesi & 53 & 4,04 & 0,65 & Katıliyorum \\
\hline 3 & Uluslararası alanda faizsiz bankacılık ve finansa yönelik trendin mevcut olması & 53 & 3,92 & 0,85 & Katılıyorum \\
\hline 4 & Katılım bankalarının ve diğer faizsiz finans kuruluşlarının sayısının giderek artması & 53 & 4,11 & 0,78 & Kat1liyorum \\
\hline 5 & Siyasi ve toplumsal iklimin uygunluğu & 53 & 3,94 & 0,79 & Katıliyorum \\
\hline 6 & Faizsiz bankacılık ve finans alanında araştırma merkezlerinin giderek artması & 53 & 3,92 & 0,73 & Katıliyorum \\
\hline 7 & $\begin{array}{l}\text { Üniversiteler bünyesinde faizsiz bankacılık ve finansla ilgili lisans, yüksek lisans ve } \\
\text { doktora programlarının açılması ve derslerin okutulması }\end{array}$ & 53 & 3,98 & 0,75 & Katıliyorum \\
\hline 8 & $\begin{array}{l}\text { Faizsiz bankacılık ve finans alanında bilimsel etkinliklerin (kongre, çalıştay vs.) dü- } \\
\text { zenlenmesi }\end{array}$ & 53 & 4,00 & 0,81 & Katıliyorum \\
\hline 9 & $\begin{array}{l}\text { Kalkınma Planında (2014-2018) faizsiz bankacılığın ve finansın geliştirilmesine yer } \\
\text { verilmesi }\end{array}$ & 53 & 3,94 & 0,74 & Katıliyorum \\
\hline & TTALAMA & 53 & 3,96 & 0,78 & Katıliyorum \\
\hline
\end{tabular}

Tablo 9'da katılım bankası çalışanlarının anketin C bölümünde yer alan "faizsiz finans muhasebe standartlarının uygulanmasını kolaylaştırıcı nedenler" ile ilgili ifadelerin tamamına katılım düzeylerinin "katılıyorum" yönünde olduğu görülmektedir. Bu sonuç, katılım bankası çalışanlarının faizsiz muhasebe standartlarının uygulanmasını kolaylaştırıcı birçok unsurun var olduğu yönünde genel bir kanıya sahip oldukları şeklinde yorumlanabilir.

Anketin $B$ ve $C$ bölümlerinde yer alan ifadeler bir arada değerlendirildiğinde, katılım bankası çalışanlarının; faizsiz finans muhasebe standartlarının uygulanmasında katılım bankalarının zorlanacağı yönde genel bir kanıya sahip olmalarına rağmen, faizsiz finans muhasebe standartlarının uygulanmasını kolaylaştırıcı unsurların varlığı nedeni ile söz konusu zorlukların aşılabileceği düşüncesine sahip oldukları şeklinde yorumlanabilir. 


\section{S. A. Şenel - Ö. Arslan 12/2 (2020) 1394-1414}

Bilindiği gibi faizsiz finans muhasebe standartları 1 Ocak 2020 veya sonrasında başlayan yıllık hesap dönemlerinde ihtiyari olarak uygulanabilecektir. Bu durum katılım bankaları için bir geçiş sürecidir. Geçiş süreçleri her zaman sancılıdır. Bu bağlamda katılım bankası çalışanlarının anketin $B$ ve $C$ bölümlerine verdikleri cevaplar doğrultusunda faizsiz finans muhasebe standartlarının uygulanmasında bir takım zorluklar olacağ ancak geçiş sürecinde yaşanacak bu zorlukların çözüme kavuşturulacağı görüşünde oldukları sonucuna varılabilir.

Anketin D bölümünde katılım bankası çalışanlarının "faizsiz finans muhasebe standartlarının uygulanmasına yönelik düşünceleri" ile ilgili 13 ifade yer almaktadır. Katılım bankası çalışanlarının bu ifadelere verdikleri cevaplara ilişkin olarak bulunan, aritmetik ortalama $(\overline{\boldsymbol{x}})$ ve standart sapma (ss) değerleri ve bu değerlerin karşıllğı olan katılım düzeyleri Tablo 10'da gösterilmiştir.

Tablo 10: Katılım Bankası Çalışanlarının FFM Muhasebe Standartlarının Uygulanması Düşüncesine İlişkin Katılım Düzeyleri

\begin{tabular}{|c|c|c|c|c|c|}
\hline \multicolumn{6}{|c|}{ Faizsiz Finans Muhasebe Standartlarının Uygulanmasına Yönelik Düşünceler } \\
\hline No & İfadeler & $\mathbf{n}$ & $\bar{x}$ & ss & Katılım Düzeyi \\
\hline 1 & $\begin{array}{l}\text { Faizsiz finans muhasebe standartlarının uygulanması ile dünyadaki aynı tür- } \\
\text { den diğer bankaların finansal tablolarıyla uyum sağlanacağını düşünüyorum }\end{array}$ & 53 & 3,96 & 0,71 & Katıliyorum \\
\hline 2 & $\begin{array}{l}\text { Faizsiz finans muhasebe standartlarının uygulanması ile finansal tablolarda } \\
\text { gerçeğe uygun sunumun sağlamış olacaktır. }\end{array}$ & 53 & 3,96 & 0,83 & Katıliyorum \\
\hline 3 & $\begin{array}{l}\text { Faizsiz finans muhasebe standartlarının uygulanması ile finansal raporlama } \\
\text { sürecinde muhasebecilere rehberlik sağlanmış olacaktır }\end{array}$ & 53 & 3,91 & 0,86 & Katıliyorum \\
\hline 4 & $\begin{array}{l}\text { Faizsiz finans muhasebe standartlarının uygulanması ile karşılaştırılabilir } \\
\text { finansal bilgiye ilişkin yeterli düzeyde açıklama sunulmuş olacaktır. }\end{array}$ & 53 & 3,98 & 0,57 & Katıliyorum \\
\hline 5 & $\begin{array}{l}\text { Faizsiz finans muhasebe standartlarının uygulanması ile kullanıcıların finan- } \\
\text { sal raporlara duyduğu güvenin artmış olacaktır. }\end{array}$ & 53 & 3,98 & 0,72 & Katıliyorum \\
\hline 6 & $\begin{array}{l}\text { Faizsiz finans muhasebe standartlarının uygulanması ile faiz hassasiyeti olan } \\
\text { uluslararası yatırımcıların güveninde artış yaşanmış olacaktır }\end{array}$ & 53 & 3,96 & 0,71 & Katıliyorum \\
\hline 7 & $\begin{array}{l}\text { Faizsiz finans muhasebe standartlarının uygulanması ile finansal tabloların } \\
\text { uluslararası geçerliliğinde artış yaşanmış olacaktır. }\end{array}$ & 53 & 3,70 & 0,77 & Katıliyorum \\
\hline 8 & $\begin{array}{l}\text { Faizsiz finans muhasebe standartlarının uygulanması ile katılım bankalarına } \\
\text { ait finansal tabloların mevduat bankalarına ait finansal tablolarla karşılaştırıl- } \\
\text { masında zorluklar yaşanacaktır. }\end{array}$ & 53 & 3,79 & 0,95 & Katıliyorum \\
\hline 9 & $\begin{array}{l}\text { Faizsiz finans muhasebe standartlarının uygulanması ile kullanıcıların finan- } \\
\text { sal bilgileri yorumlamaları değişiklik gösterecektir. }\end{array}$ & 53 & 4,02 & 0,64 & Katılıyorum \\
\hline 10 & $\begin{array}{l}\text { Faizsiz finans muhasebe standartlarının uygulanması ile kullanıcıların karar } \\
\text { alması zorlaşacaktır. }\end{array}$ & 53 & 3,64 & 0,94 & Katıliyorum \\
\hline 11 & $\begin{array}{l}\text { Faizsiz finans muhasebe standartlarının uygulanması ile dış denetçilerin iş yü- } \\
\text { künde gereksiz artış yaşanacaktır. }\end{array}$ & 53 & 3,45 & 0,89 & Katıliyorum \\
\hline 12 & $\begin{array}{l}\text { Faizsiz finans muhasebe standartlarının uygulanması ile muhasebeciler uyum } \\
\text { göstermede büyük zorluk yaşayacaktır }\end{array}$ & 53 & 3,74 & 0,88 & Katıliyorum \\
\hline 13 & $\begin{array}{l}\text { Faizsiz finans muhasebe standartlarının uygulanması ile muhasebecilerin } \\
\text { uyumu için ilave eğitim maliyetleri ortaya çlkacaktır. }\end{array}$ & 53 & 3,91 & 0,74 & Katıliyorum \\
\hline ORT & ГALAMA & 53 & 3,85 & 0,79 & Kat1liyorum \\
\hline
\end{tabular}

Tablo 10 incelendiğinde katılım bankası çalışanlarının faizsiz finans muhasebe standartlarının uygulanmasına yönelik düşüncelere katılım düzeyleri “katılıyorum” yönünde olduğu görülmektedir. Katılım bankası çalışanlarının görüşüne göre faizsiz finans muhasebe standartlarına geçiş sürecinde; muhasebe meslek mensupları açısından ilave eğitim maliyetlerinin ortaya çıkacak olması, faizsiz finans muhasebe standartlarına uyum göstermede büyük zorluk yaşanacağı, dış denetçilerin iş yükünde gereksiz artış olacağı ve katılım bankalarına ait finansal tabloların mevduat bankalarına ait finansal tablolarla karşılaştırılmasında zorluklar yaşanacak olması ortaya çıkabilecek sorunlar olarak görülmektedir. Bununla birlikte katılım bankası çalışanları faizsiz finans muhasebe standartlarının uygulanması ile dünyadaki aynı türden diğer bankaların finansal tablolarıyla uyum sağlanacağı, faiz hassasiyeti olan uluslararası yatırımcıların güveninde artış yaşanacağı, finansal raporlara duyulan güvenin artacağı ve belki de en önemlisi finansal tablolarda gerçeğe uygun sunumun sağlanmış olacağı görüşündedirler. 


\section{S. A. Şenel - Ö. Arslan 12/2 (2020) 1394-1414}

Anketin E bölümünde katılım bankası çalışanlarının, 10 başlık altında sıralanan kişi veya kurumların "faizsiz finans muhasebe standartlarının uygulanmasında önem derecesini" belirtmeleri istenmiştir. Katılım bankası çalışanlarının verdikleri cevaplara ilişkin olarak bulunan, aritmetik ortalama $(\overline{\boldsymbol{x}})$ ve standart sapma (ss) değerleri ve bu değerlerin karşılı̆̆ olan katılım düzeyleri Tablo 11'de gösterilmiştir.

Tablo 11: Katılım Bankası Çalışanlarının FFM Standartlarının Uygulanmasında Kişi veya Kurumların Önem Derecesine Yönelik İfadelere Katılım Düzeyleri

\begin{tabular}{clcccc}
\hline \multicolumn{1}{c}{ Faizsiz Finans Muhasebe Standartlarının Uygulanmasında Kişi veya Kurumların Önem Derecesi } \\
\hline \multicolumn{1}{c}{ İfadeler } & $\mathbf{n}$ & $\overline{\boldsymbol{x}}$ & ss & Katılım Düzeyi \\
\hline 1 & Türkiye Cumhuriyet Merkez Bankası (TCMB) & 53 & 4,53 & 0,58 & Çok Önemli \\
2 & Bankacılık Düzenleme ve Denetleme Kurulu (BDDK) & 53 & 4,58 & 0,53 & Çok Önemli \\
3 & Türkiye Serbest Muhasebeciler ve Mali Müşavirler Odaları Birliği (TÜRMOB) & 53 & 4,11 & 0,82 & Önemli \\
4 & Kamu Gözetimi Muhasebe ve Denetim Standartları Kurumu (KGK) & 53 & 4,32 & 0,61 & Çok Önemli \\
5 & Türkiye Katılım Bankaları Birliği (TKBB) & 53 & 4,60 & 0,53 & Çok Önemli \\
6 & Sermaye Piyasası Kurulu (SPK) & 53 & 4,55 & 0,57 & Çok Önemli \\
7 & Bağımsız denetim firmaları & 53 & 4,15 & 0,69 & Önemli \\
8 & Muhasebe alanında uzman akademisyenler & 53 & 4,21 & 0,72 & Çok Önemli \\
9 & Faizsiz bankacılık ve finans temsilcileri & 53 & 4,55 & 0,50 & Çok Önemli \\
10 & İgili Bakanlık(lar) & 53 & 4,49 & 0,58 & Çok Önemli \\
\hline ORTALAMA & $\mathbf{5 3}$ & $\mathbf{4 , 4 1}$ & $\mathbf{0 , 6 1}$ & Çok Önemli \\
\hline
\end{tabular}

Tablo 11'de katılım bankası çalışanlarının anketin E bölümünde 10 başlık altında sıralanan kişi veya kurumların faizsiz finans muhasebe standartlarının uygulanmasında önem derecesini belirtmelerine ilişkin olarak verdikleri cevaplarda, katılım düzeyinin, iki kurum hariç, "Çok Önemli" yönünde olduğu görülmektedir. Bu sonuç, katılım bankası çalışanlarının faizsiz finans muhasebe standartlarının uygulanmasında Türkiye Serbest Muhasebeciler ve Mali Müşavirler Odaları Birliği (TÜRMOB) ve bağımsız denetim firmalarının "önemli", ankette yer alan diğer kişi ve kurumların ise "çok önemli" etkileri olacağı düşüncesinde oldukları şeklinde yorumlanabilir.

\subsection{Anlamlilık Analizleri}

Bulgular ve yorum bölümünün son aşamasında, veriler normal dağglım göstermediği için araştırmaya katılan katılım bankası çalışanlarının faizsiz finans muhasebe standartlarının uygulanmasına yönelik katılım düzeylerinin demografik değişkenlere göre farklılık gösterip göstermediği çözümlemeye dâhil edilmiş ve bazı karşılaştırmalar yapılmıştır.

Katılım bankası çalışanlarının;

1. Cinsiyetlerine göre iki

2. Yaşlarına göre iki

3. Bilgi düzeylerine göre iki

4. Çalıştıkları bankaların sermaye yapısına göre iki

5. Eğitim düzeylerine göre üç

6. Mesleki deneyimlerine göre üç ayrı grup görüşleri ele alınmıştır.

"Gruplar arasında anlamlı bir fark yoktur" hipotezi $\mathrm{P}=0,05$ anlamlılık düzeyinde, ikili gruplar için Mann Whitney $\mathrm{U}$ testi, ikiden fazla olan gruplar için ise Kruskal Wallis testi yapılmıştır. Yapılan test sonucunda $\mathrm{P}<$ 0,05 ise gruplar arasında anlamlı fark olduğuna $\mathrm{P} \geq 0,05$ ise gruplar arasında anlamlı fark olmadığına karar verilir(Karagöz 2010:19).

Anketin B, C, D ve E bölümlerinde yer alan her bir ifadeye katılım bankası çalışanlarının verdikleri cevaplar dikkate alınarak her bölüm için ölçek puanı B Bölümü (En düşük 11; En yüksek 55), C Bölümü (En düşük 9; En yüksek 45), D Bölümü (En düşük 13; En yüksek 65) ve E Bölümü (En düşük 10; En yüksek 50) olarak hesaplanmıştır. 


\section{S. A. Şenel - Ö. Arslan 12/2 (2020) 1394-1414}

Bu bölümlere ait ölçek puanları dikkate alınarak katılım bankası çalışanlarının cinsiyetlerine, yaşlarına, bilgi düzeylerine, çalıştıkları bankaların sermaye yapısına, eğitim düzeylerine ve mesleki deneyimlerine göre farklılık gösterip göstermediğini açıklayan sonuçlar tablolar halinde aşağıda yer almaktadır.

Tablo 12: Katılım Bankası Çalışanlarının Cinsiyetleri ile Anketteki Bölümler Arasındaki Farklılık Düzeyi

\begin{tabular}{|c|c|c|c|c|c|c|c|}
\hline Anketteki Bölümler & Cinsiyet & $\mathbf{N}$ & Mean Rank & Sum Of Ranks & Mann Whitney U & $\mathbf{Z}$ & $\mathbf{P}$ \\
\hline \multirow{2}{*}{ B Bölümü } & Kadın & 13 & 32,88 & 427,5 & \multirow{2}{*}{183,5} & \multirow{2}{*}{$-1,585$} & \multirow{2}{*}{0,113} \\
\hline & Erkek & 40 & 25,09 & 1003,5 & & & \\
\hline \multirow{2}{*}{ C Bölümü } & Kadın & 13 & 26,08 & 339,0 & \multirow{2}{*}{248,0} & \multirow{2}{*}{$-0,249$} & \multirow{2}{*}{0,803} \\
\hline & Erkek & 40 & 27,30 & 1092,0 & & & \\
\hline \multirow{2}{*}{ D Bölümü } & Kadın & 13 & 27,92 & 363,0 & \multirow{2}{*}{248,0} & \multirow{2}{*}{$-0,249$} & \multirow{2}{*}{0,804} \\
\hline & Erkek & 40 & 26,70 & 1068,0 & & & \\
\hline \multirow{2}{*}{ E Bölümü } & Kadın & 13 & 26,08 & 339,0 & \multirow{2}{*}{248,0} & \multirow{2}{*}{$-0,250$} & \multirow{2}{*}{0,802} \\
\hline & Erkek & 40 & 27,30 & 1092,0 & & & \\
\hline
\end{tabular}

Tablo 12' de görüldüğ̈̈ üzere anketin B, C, D ve E bölümlerinde yer alan ifadelere katılım düzeylerinde katılım bankası çalışanlarının cinsiyetleri açısından 0,05 anlamlılık düzeyinde bir farklılık olup olmadığını tespit etmek üzere yapılan analiz sonucunda, her bölüm için $P \geq 0,05$ olarak tespit edilmiştir. Bu sonuç, anketin $B, C$, $D$ ve $E$ bölümlerinde yer alan ifadelere katılım düzeylerinde katılım bankası çalışanlarının cinsiyetleri açısından 0,05 anlamlılık düzeyinde anlamlı bir farklılık olmadığını göstermektedir.

Tablo 13: Katılım Bankası Çalışanlarının Yaşları ile Anketteki Bölümler Arasındaki Farklılık Düzeyi

\begin{tabular}{|c|c|c|c|c|c|c|c|}
\hline Anketteki Bölümler & Yaş Aralı̆̆ı & $\mathbf{N}$ & Mean Rank & Sum Of Ranks & Mann Whitney U & $\mathbf{Z}$ & $\mathbf{P}$ \\
\hline \multirow{2}{*}{ B Bölümü } & $23-34$ & 32 & 23,36 & 747,5 & \multirow{2}{*}{219,5} & \multirow{2}{*}{$-2,124$} & \multirow{2}{*}{0,034} \\
\hline & $35-44$ & 21 & 32,55 & 683,5 & & & \\
\hline \multirow{2}{*}{ C Bölümü } & $23-34$ & 32 & 23,38 & 748,0 & \multirow{2}{*}{220,0} & \multirow{2}{*}{$-2,121$} & \multirow{2}{*}{0,034} \\
\hline & $35-44$ & 21 & 32,52 & 683,0 & & & \\
\hline \multirow{2}{*}{ D Bölümü } & $23-34$ & 32 & 23,58 & 754,5 & \multirow{2}{*}{226,5} & \multirow{2}{*}{$-1,995$} & \multirow{2}{*}{0,046} \\
\hline & $35-44$ & 21 & 32,21 & 676,5 & & & \\
\hline \multirow{2}{*}{ E Bölümü } & $23-34$ & 32 & 26,84 & 859,0 & \multirow{2}{*}{331,0} & \multirow{2}{*}{$-0,092$} & \multirow{2}{*}{0,927} \\
\hline & $35-44$ & 21 & 27,24 & 572,0 & & & \\
\hline
\end{tabular}

Tablo 13'de görüldüğ ü üzere anketin B, C, D ve E bölümlerinde yer alan ifadelere katılım düzeylerinde katılım bankası çalışanlarının yaşları açısından 0,05 anlamlılık düzeyinde bir farklılık olup olmadığını tespit etmek üzere yapılan analiz sonucunda, anketin $B, C$ ve $D$ bölümleri için $P<0,05$, E bölümü için ise $P \geq 0,05$ olarak tespit edilmiştir. Bu sonuç, anketin $\mathrm{B}, \mathrm{C}$ ve $\mathrm{D}$ bölümlerinde yer alan ifadelere katılım düzeylerinde katılım bankası çalışanlarının yaşları açısından 0,05 anlamlılık düzeyinde anlamlı bir farklılık olduğunu göstermektedir. Buna göre 35-44 yaş aralığında olan katılım bankası çalışanlarının, faizsiz finans muhasebe standartlarının uygulanmasını zorlaştıracak nedenlere (anketin B bölümü), faizsiz finans muhasebe standartlarının uygulanmasını kolaylaştırıcı nedenlere (anketin C bölümü) ve faizsiz finans muhasebe standartlarının uygulanmasına yönelik düşüncelere (anketin D bölümü) 23-34 yaşa aralığında olan katılım bankası çalışanlarına göre daha olumlu yönde katılım gösterdikleri sonucuna varılabilir. Anketin E bölümünde yer alan ifadelere katılım düzeylerinde ise katılım bankası çalışanlarının yaşları açısından 0,05 anlamlılık düzeyinde anlamlı bir farklılık olmadığı görülmektedir. Faizsiz finans muhasebe standartlarının uygulanmasında kişi veya kurumların önem derecesi (anketin E bölümü) katılım bankası çalışanlarının yaşları açısından değişiklik göstermemiştir. Her iki yaş grubu içinde önem derecelerinin aynı olduğu sonucuna varılabilir.

Tablo 14: Katılım Bankası Çalışanlarının Faizsiz Finans Muhasebe Standartları Hakkındaki Bilgi Düzeyleri İle Anketteki Bölümler Arasındaki Farklılık Düzeyi

\begin{tabular}{|c|c|c|c|c|c|c|c|}
\hline Anketteki Bölümler & Bilgi Düzeyi & $\mathbf{N}$ & Mean Rank & Sum Of Ranks & Mann Whitney U & $\mathrm{Z}$ & $\mathbf{P}$ \\
\hline \multirow{2}{*}{ B Bölümü } & Haberdarım & 40 & 28,01 & 1120,5 & \multirow{2}{*}{219,5} & \multirow{2}{*}{$-0,839$} & \multirow{2}{*}{0,401} \\
\hline & Haberdar Değilim & 13 & 23,88 & 310,5 & & & \\
\hline \multirow{2}{*}{ C Bölümü } & Haberdarım & 40 & 27,64 & 1105,5 & \multirow{2}{*}{234,5} & \multirow{2}{*}{$-0,530$} & \multirow{2}{*}{0,596} \\
\hline & Haberdar Değilim & 13 & 25,04 & 325,5 & & & \\
\hline \multirow{2}{*}{ D Bölümü } & Haberdarım & 40 & 29,51 & 1180,5 & \multirow{2}{*}{159,5} & \multirow{2}{*}{$-2,082$} & \multirow{2}{*}{0,037} \\
\hline & Haberdar Değilim & 13 & 19,27 & 250,5 & & & \\
\hline \multirow{2}{*}{ E Bölümü } & Haberdarım & 40 & 26,46 & 1058,5 & \multirow{2}{*}{238,5} & \multirow{2}{*}{$-0,448$} & \multirow{2}{*}{0,654} \\
\hline & Haberdar Değilim & 13 & 28,60 & 372,5 & & & \\
\hline
\end{tabular}




\section{S. A. Şenel - Ö. Arslan 12/2 (2020) 1394-1414}

Tablo 14'de görüldüğü üzere anketin B, C, D ve E bölümlerinde yer alan ifadelere katılım düzeylerinde katılım bankası çalışanlarının faizsiz finans muhasebe standartları hakkındaki bilgi düzeyleri açısından 0,05 anlamlılık düzeyinde bir farklılık olup olmadığını tespit etmek üzere yapılan analiz sonucunda, anketin $\mathrm{B}, \mathrm{C}$ ve $\mathrm{E}$ bölümleri için $\mathrm{P}<0,05$, $\mathrm{D}$ bölümü için ise $\mathrm{P} \geq 0,05$ olarak tespit edilmiştir. Bu sonuç, anketin $\mathrm{B}, \mathrm{C}$ ve $\mathrm{E}$ bölümlerinde yer alan ifadelere katılım düzeylerinde katılım bankası çalışanlarının faizsiz finans muhasebe standartları hakkındaki bilgi düzeyleri açısından 0,05 anlamlılık düzeyinde anlamlı bir farklılık olmadığını göstermektedir. Ancak, katılım bankası çalışanlarının faizsiz finans muhasebe standartlarının uygulanmasına yönelik düşüncelere (anketin D bölümü) katılım düzeylerinde faizsiz finans muhasebe standartları hakkındaki bilgi düzeyleri açısından 0,05 anlamlılık düzeyinde anlamlı bir farklılık olduğu görülmektedir. Buna göre faizsiz finans muhasebe standartlarından haberdar olan katılım bankası çalışanlarının, faizsiz finans muhasebe standartlarının uygulanmasına yönelik düşüncelere katılım seviyelerinin haberdar olmayanlara göre daha olumlu yönde olduğu sonucuna varılabilir.

Tablo 15: Katılım Bankası Çalışanlarının Çalıştıkları Bankaların Sermaye Yapısı ile Anketteki Bölümler Arasındaki Farklılık Düzeyi

\begin{tabular}{|c|c|c|c|c|c|c|c|}
\hline Anketteki Bölümler & Sermaye Yapısı & $\mathbf{N}$ & Mean Rank & Sum Of Ranks & Mann Whitney U & $\mathrm{Z}$ & $\mathbf{P}$ \\
\hline \multirow{2}{*}{ B Bölümü } & Özel & 30 & 23,02 & 529,5 & \multirow{2}{*}{253,5} & \multirow{2}{*}{$-1,646$} & \multirow{2}{*}{0,100} \\
\hline & Kamu & 23 & 30,05 & 901,5 & & & \\
\hline \multirow{2}{*}{ C Bölümü } & Özel & 30 & 24,43 & 562,0 & \multirow{2}{*}{286,0} & \multirow{2}{*}{$-1,065$} & \multirow{2}{*}{0,287} \\
\hline & Kamu & 23 & 28,97 & 869,0 & & & \\
\hline \multirow{2}{*}{ D Bölümü } & Özel & 30 & 22,00 & 506,0 & \multirow{2}{*}{230,0} & \multirow{2}{*}{$-2,068$} & \multirow{2}{*}{0,039} \\
\hline & Kamu & 23 & 30,83 & 925,0 & & & \\
\hline \multirow{2}{*}{ E Bölümü } & Özel & 30 & 28,67 & 659,5 & \multirow{2}{*}{306,5} & \multirow{2}{*}{$-0,697$} & \multirow{2}{*}{0,486} \\
\hline & Kamu & 23 & 25,72 & 771,5 & & & \\
\hline
\end{tabular}

Tablo 15'de görüldüğü üzere anketin B, C, D ve E bölümlerinde yer alan ifadelere katılım düzeylerinde katılım bankası çalışanlarının çalıştıkları bankaların sermaye yapısı açısından 0, 05 anlamlılık düzeyinde bir farklılık olup olmadığını tespit etmek üzere yapılan analiz sonucunda, anketin $B, C$ ve $E$ bölümleri için $P<0,05, D$ bölümü için ise $P \geq 0,05$ olarak tespit edilmiştir. Bu sonuç, anketin $B, C$ ve $E$ bölümlerinde yer alan ifadelere katılım düzeylerinde katılım bankası çalışanlarının çalıştıkları bankaların sermaye yapısı açısından 0,05 anlamlılık düzeyinde anlamlı bir farklılık olmadığını göstermektedir. Ancak, katılım bankası çalışanlarının faizsiz finans muhasebe standartlarının uygulanmasına yönelik düşüncelere (anketin D bölümü) katılım düzeylerinde çalıştıkları bankaların sermaye yapısı açısından 0,05 anlamlılık düzeyinde anlamlı bir farklılık olduğu görülmektedir. Buna göre sermayesi kamuya ait olan katılım bankalarında çalışan bankacıların faizsiz finans muhasebe standartlarının uygulanmasına yönelik düşüncelere, sermayesi özel girişimcilere ait olan katılım bankalarında çalışan bankacılara göre daha olumlu yönde katılım gösterdikleri sonucuna varılabilir.

Tablo 16: Katılım Bankası Çalışanlarının Eğitim Durumlarına Göre Anketteki Bölümler Arasındaki Farklılık Düzeyi

\begin{tabular}{|c|c|c|c|c|c|c|}
\hline Anketteki Bölümler & Eğitim Seviyesi & $\mathbf{N}$ & Mean Rank & Chi-square & df & $\mathbf{P}$ \\
\hline \multirow{3}{*}{ B Bölümü } & Ön Lisans & 5 & 25,10 & & & \\
\hline & Lisans & 44 & 26,72 & 0,601 & 2 & 0,740 \\
\hline & Yüksek Lisans & 4 & 32,50 & & & \\
\hline \multirow{3}{*}{ C Bölümü } & Ön Lisans & 5 & 34,90 & & & \\
\hline & Lisans & 44 & 26,27 & 1,481 & 2 & 0,477 \\
\hline & Yüksek Lisans & 4 & 25,13 & & & \\
\hline \multirow{3}{*}{ D Bölümü } & Ön Lisans & 5 & 37,70 & & & \\
\hline & Lisans & 44 & 25,82 & 2,672 & 2 & 0,263 \\
\hline & Yüksek Lisans & 4 & 26,83 & & & \\
\hline \multirow{3}{*}{ E Bölümü } & Ön Lisans & 5 & 16,30 & & & \\
\hline & Lisans & 44 & 27,42 & 3,779 & 2 & 0,151 \\
\hline & Yüksek Lisans & 4 & 35,75 & & & \\
\hline
\end{tabular}

Tablo 16' da görüldüğü üzere anketin B, C, D ve E bölümlerinde yer alan ifadelere katılım düzeylerinde katılım bankası çalışanlarının eğitim durumlarına göre 0,05 anlamlılık düzeyinde bir farklılık olup olmadığını tespit etmek üzere yapılan analiz sonucunda, her bölüm için $\mathrm{P} \geq 0,05$ olarak tespit edilmiştir. Bu sonuç, anketin B, C, 


\section{S. A. Şenel - Ö. Arslan 12/2 (2020) 1394-1414}

D ve E bölümlerinde yer alan ifadelere katılım düzeylerinde katılım bankası çalışanlarının eğitim durumlarına göre 0,05 anlamlılık düzeyinde anlamlı bir farklılık olmadığını göstermektedir.

Tablo 17: Katılım Bankası Çalışanlarının Mesleki Deneyimi ile Anketteki Bölümler Arasındaki Farklılık Düzeyi

\begin{tabular}{|c|c|c|c|c|c|c|}
\hline Anketteki Bölümler & Mesleki Deneyim & $\mathbf{N}$ & Mean Rank & Chi-square & df & $\mathbf{P}$ \\
\hline \multirow{3}{*}{ B Bölümü } & $1-5$ yıl & 21 & 21,86 & \multirow{3}{*}{3,906} & \multirow{3}{*}{2} & \multirow{3}{*}{0,142} \\
\hline & 6-9 yil & 16 & 29,91 & & & \\
\hline & $10-15$ yıl & 16 & 30,84 & & & \\
\hline \multirow{3}{*}{ C Bölümü } & $1-5$ yıl & 21 & 24,45 & \multirow{3}{*}{3,998} & \multirow{3}{*}{2} & \multirow{3}{*}{0,135} \\
\hline & $6-9$ yil & 16 & 23,94 & & & \\
\hline & $10-15$ yıl & 16 & 33,41 & & & \\
\hline \multirow{3}{*}{ D Bölümü } & $1-5$ yıl & 21 & 24,10 & \multirow{3}{*}{1,426} & \multirow{3}{*}{2} & \multirow{3}{*}{0,490} \\
\hline & $6-9$ yil & 16 & 27,72 & & & \\
\hline & $10-15$ yıl & 16 & 30,09 & & & \\
\hline \multirow{3}{*}{ E Bölümü } & $1-5$ yıl & 21 & 27,24 & \multirow{3}{*}{0,052} & \multirow{3}{*}{2} & \multirow{3}{*}{0,975} \\
\hline & 6-9 yıl & 16 & 26,28 & & & \\
\hline & $10-15 \mathrm{yll}$ & 16 & 27,41 & & & \\
\hline
\end{tabular}

Tablo 17' de görüldüğü üzere anketin B, C, D ve E bölümlerinde yer alan ifadelere katılım düzeylerinde katılım bankası çalışanlarının mesleki deneyimleri açısından 0,05 anlamlılık düzeyinde bir farklılık olup olmadığını tespit etmek üzere yapılan analiz sonucunda, her bölüm için $\mathrm{P} \geq 0,05$ olarak tespit edilmiştir. Bu sonuç, anketin B, C, D ve E bölümlerinde yer alan ifadelere katılım düzeylerinde katılım bankası çalışanlarının mesleki deneyimleri açısından 0,05 anlamlılık düzeyinde anlamlı bir farklılık olmadığını göstermektedir.

\section{Değerlendirme ve Sonuç}

Sivas il merkezinde faaliyet gösteren katılım bankası çalışanlarının faizsiz finans muhasebe standartlarına yönelik farkındalık düzeylerini belirlemek ve faizsiz finans muhasebe standartlarının katılım bankalarında uygulanabilirliğine ilişkin düşüncelerini tespit etmek amacıyla yapılan bu çalışmada veri toplama tekniği olarak anket yöntemi kullanılmıştır. Araştırmanın evrenini Sivas il merkezinde faaliyet gösteren beş katılım bankasında çalışan kişiler oluşturmaktadır. Anket verilerinin analizinde, SPSS 22 for Windows (Social Package Statiscal Science) istatistiksel paket programından yararlanılmıştır.

Araştırma sonuçlarına göre Sivas il merkezinde faaliyet gösteren katılım bankası çalışanları, Türkiye'nin Müslüman bir ülke olması, hükümetin faizsiz finans sistemini ve faizsiz bankacılığı geliştirici politikalar izlemesi, katılım bankalarının ve diğer faizsiz finans kuruluşlarının sayılarının giderek artması gibi durumlardan dolayı faizsiz finans muhasebe standartlarının uygulanmasının kolaylaşabileceğini vurgulamışlardır. Ayrıca, üniversiteler bünyesinde faizsiz bankacılık ve faizsiz finansla ilgili lisans, yüksek lisans ve doktora programlarının açılması ve derslerin okutulması, Kalkınma Planında (2014-2018) faizsiz bankacılığın ve finansın geliştirilmesine yer verilmesi halinde de faizsiz finans muhasebe standartlarının uygulanmasının ivme kazanacağını düşünmektelerdir. Bu olumlu durumların yanında da faizsiz finans muhasebe standartlarıyla ilgili farkındalığın oluşmadığını, katılım bankalarının henüz böyle bir değişikliğe hazır olmadığını ve faizsiz finans muhasebe standartlarının uygulanmasının birçok yasal engele takılacağı gibi olumsuz durumların da varlığına dikkat çekmişlerdir.

Katılım bankası çalışanları tarafından faizsiz finans muhasebe standartlarının uygulanması ile Türkiye'de faaliyet gösteren katılım bankalarının finansal tablolarının dünyadaki aynı türden diğer bankaların finansal tablolarıyla uyum sağlayacağını, finansal raporlama sürecinde muhasebe meslek mensuplarına rehberlik edebileceğini, finansal raporlara duyulan güvenin artacağını ve finansal tabloların uluslararası alanda geçerliliğinde artış yaşanacağını belirtilmiştir. Bununla beraber faizsiz finans muhasebe standartların uygulanmasının muhasebe meslek mensupları ve denetçilerin iş yüklerinin ve faizsiz finans muhasebe standartlarını öğrenmek için eğitim masraflarının artacağına da belirtmişlerdir. 


\section{S. A. Şenel - Ö. Arslan 12/2 (2020) 1394-1414}

Ayrıca katılım bankası çalışanları faizsiz finans muhasebe standartlarının uygulanmasında Türkiye Cumhuriyet Merkez Bankası (TCMB), Bankacılık Düzenleme ve Denetleme Kurulu (BDDK), Kamu Gözetimi Muhasebe ve Denetim Standartları Kurumu (KGK), Türkiye Katılım Bankaları Birliği (TKBB), Sermaye Piyasası Kurulu (SPK) gibi kurumların, ilgili Bakanlıkların, muhasebe alanında uzman akademisyenlerin, faizsiz bankacılık ve finans temsilcilerinin "çok önemli", Türkiye Serbest Muhasebeciler ve Mali Müşavirler Odaları Birliği (TÜRMOB) ve bağımsız denetim firmalarının ise "önemli" etkileri olacağını vurgulamışlardır.

Anketin demografik yapı ve genel bilgilerin yer aldığı A bölümüne ilişkin sonuçlar şu şekildedir. Sivas il merkezinde faaliyet gösteren katılım bankası çalışanlarının \%60'ı 23-34, geriye kalanı ise 35-44 yaş aralığındadır. \%9'u ön lisans, \%83'ü lisans, \%8'i ise yüksek lisans mezunudur ve \%24,5'i kadın, \%75,5'i ise erkek çalışandan oluşmaktadır. Sivas il merkezinde faaliyet gösteren katılım bankası çalışanlarının \%40'ı 1-5, geriye kalanı ise 6-15 yıllık mesleki deneyime sahiptir ve \%43'ünün kamu, \%57'sinin ise özel bankalarda çalıştığı görülmektedir. Ayrıca katılım bankası çalışanlarının \%75'i Kamu Gözetimi Muhasebe ve Denetim Standartları Kurumu (KGK) tarafindan yayımlanan faizsiz finans muhasebe standartlarından haberdardır ve faizsiz finans muhasebe standartlarının uygulanması fikrini "çok olumlu" ve "olumlu" olarak görenlerin oranı \%87'dir.

Anketin faizsiz finans muhasebe standartlarının uygulanmasını zorlaştıracak nedenlere ilişkin ifadelerin yer aldığı B bölümü, faizsiz finans muhasebe standartlarının uygulanmasını kolaylaştırıcı nedenlere ilişkin ifadelerin yer aldığ $\mathrm{C}$ bölümü, faizsiz finans muhasebe standartlarının uygulanmasına yönelik düşüncelere ilişkin ifadelerin yer aldığı $\mathrm{D}$ bölümü ve faizsiz finans muhasebe standartlarının uygulanmasında kişi veya kurumların önem derecesine ilişkin ifadelerin yer aldığı $\mathrm{E}$ bölümüne ilişkin sonuçlar değerlendirildiğinde katılım bankası çalışanlarının;

$\checkmark$ Cinsiyetleri açısından anketin B, C, D ve E bölümlerinde yer alan ifadelere,

$\checkmark$ Yaşları açısından anketin $\mathrm{E}$ bölümünde yer alan ifadelere,

$\checkmark$ Bilgi düzeyleri açısından anketin B, C ve E bölümlerinde yer alan ifadelere,

$\checkmark$ Çalıştıkları bankaların sermaye yapısı açısından anketin B, C ve E bölümlerinde yer alan ifadelere,

$\checkmark$ Eğitim düzeyleri açısından anketin B, C, D ve E bölümlerinde yer alan ifadelere ve

$\checkmark$ Mesleki deneyimleri açısından anketin B, C, D ve E bölümlerinde yer alan ifadelere katılım düzeylerinde 0,05 anlamlılık düzeyinde anlamlı bir farklılık olmadığı görülmektedir

Öte yandan;

$\checkmark$ Yaşları açısından anketin B, C ve D bölümlerinde yer alan ifadelere katılım düzeylerinde 0,05 anlamlılık düzeyinde anlamlı bir farklılık olduğu görülmektedir. Buna göre 35-44 yaş aralığında olan katılım bankası çalışanları, 23-34 yaşa aralığında olan katılım bankası çalışanlarına göre anketin B, C ve D bölümlerinde yer alan ifadelere daha olumlu yönde katılım göstermişlerdir.

$\checkmark$ Bilgi düzeyleri açısından anketin D bölümünde yer alan ifadelere katılım düzeylerinde 0,05 anlamlılık düzeyinde anlamlı bir farklılık olduğu görülmektedir. Buna göre faizsiz finans muhasebe standartlarından haberdar olan katılım bankası çalışanlarının, faizsiz finans muhasebe standartlarının uygulanmasına yönelik düşüncelere katılım seviyeleri haberdar olmayanlara göre daha olumludur.

$\checkmark$ Çalıştıkları bankaların sermaye yapısı açısından anketin D bölümünde yer alan ifadelere katılım düzeylerinde 0,05 anlamlılık düzeyinde anlamlı bir farklılık olduğu görülmektedir. Buna göre sermayesi kamuya ait olan katılım bankalarında çalışan bankacıların faizsiz finans muhasebe standartlarının uygulanmasına yönelik düşüncelere, sermayesi özel girişimcilere ait olan katılım bankalarında çalışan bankacılara göre daha olumlu yönde katılım göstermişlerdir.

Faizsiz finans muhasebe standartlarının 2020 yılı itibarıyla yürürlüğe girmiş olması, Türkiye'de yakın bir zamana kadar faaliyetlerine uygun finansal raporlama ve muhasebe çerçevesine sahip bulunmayan katılım bankaları açısından bir dönüm noktası olarak kabul edilebilir. Böylelikle katılım bankaları faaliyetlerini faizsiz finans yaklaşımı çerçevesinde raporlama imkânına kavuşmuştur. Bu çalışmada Sivas il merkezinde faaliyet gösteren katılım bankası çalışanlarının faizsiz finans muhasebe standartlarına bakış açıları analiz edilmiştir. Çalışmanın bu bağlamda önemli olduğu ve ilgili literatüre önemli bir katkı sağlayacağı düşünülmektedir. Hiç şüphesiz faizsiz finans muhasebe standartlarının yayımlanması ve katılım bankalarının faaliyetlerini faizsiz finans yaklaşımı çerçevesinde raporlamaya yapmaya başlaması ile birlikte finansal sonuçları içeren veriye dayalı çalışmalar da yapılabilecektir. 


\section{S. A. Şenel - Ö. Arslan 12/2 (2020) 1394-1414 \\ Kaynakça}

Ağkan, F. (2018). AAOIFI Standartları ve Türkiye Katılım Bankalarında Uygulanabilirliği, Anemon Muş Alparslan Üniversitesi Sosyal Bilimler Dergisi, 6(2), 235 - 245.

Ahmed, S. (2006). Islamic Banking Finance and Insurance: A Global Overview, Kuala Lumpur, A. S. Nordeen,

Bakanlar Kurulu Kararı (83/7506). 19.12.1983 tarihli 18256 sayılı Resmi Gazete.

Bindak, R. (2014). Mann-Whitney U ile Student's t testinin I. Tip Hata ve Güç bakımından Karşılaştırılması: Monte Carlo Simülasyon Çalışması, Afyon Kocatepe Üniversitesi Fen ve Mühendislik Bilimleri Dergisi (AKÜ FEMÜBID), 14(1), 5-11.

Cumhurbaşkanlığı Yıllık Programı (2019).

Dinç, Y. (2016) Katılım Bankalarının Danışma Kurullarının Kurumsal Yönetim Unsuru Olarak Değerlendirilmesi, İslam Ekonomisi ve Finans Dergisi, (2), 83-103.

Döndüren H. (2008). Osmanlı Tarihinde Bazı Faizsiz Kredi Uygulamaları ve Modern Türkiye'de Faizsiz Bankacilık Tecrübesi, Uludă̆ Üniversitesi İlâhiyat Fakültesi Dergisi,17(1),1-24.

Ersoy, M. ve Süner, A. (2018). Türkiye'de Katılım Bankacılığı ve Katılım Bankacılı̆̆ında Kamu Girişimi, Marmara Üniversitesi İktisadi ve İdari Bilimler Dergisi, 40(2), 167-180.

Ersoy, M., Çatıkkaş, Ö., ve Yatbaz, A. (2018). İslami Muhasebenin Geleneksel Muhasebe ile Karşılaştırmalı Olarak İncelenmesi, Uluslararası İslam Ekonomisi ve Finansı Araştırmaları Dergisi, 4(1), 96-110.

Eskici, M. M.(2007). Türkiye'de Katılım Bankacılığı Uygulaması ve Katılım Bankalarının Müşteri Özellikleri, Süleyman Demirel Üniversitesi Sosyal Bilimler Enstitüsü, Yüksek Lisans Tezi, Isparta.

Güney, N. (2015). İslami Finansta Şer'i Yönetim Uygulamaları ve Konuyla İlgili Tartışmalara Genel Bir Bakış, Türkiye İslam İktisadı Dergisi, (2), 45-69.

Hamim, M., Naziruddin A., and Syed, H. (2006). Efficiency of Islamic Banking in Malaysia: A Stocastic Frontierapproach, Journal of Economic Cooperation, 27 (2), 37-70.

Hazine ve Dış Ticaret Müsteşarlığı Tebliği, 25.02.1984 tarihli 18323 sayılı Resmi Gazete.

Iqbal, Z. (2017). Introduction to Islamic Finance \& Banking, World Bank - BRSA - TKBB Joint Workshop on "Innovative Product Development in Islamic Banks", Istanbul, The World Bank Global Islamic Finance Development Center.

Karagöz, Y. (2010). Non-Parametrik Tekniklerin Güç ve Etkinlikleri, Elektronik Sosyal Bilimler Dergisi, 9(33), 1840. [https://dergipark.org.tr/tr/download/article-file/70201, Erişim Tarihi: 06.01.2020].

Karagöz, Y. (2017). SPSS ve Amos uygulamalı Nitel-Nicel Bilimsel Araştırma Yöntemleri, Sivas, Nobel Yayınevi.

Kartal, M. T. (2018). Türkiye'de Faizsiz Bankacılık Alanında Yayınlanmış Tezlerin Analizi, Maliye ve Finans Yazllarl, 110, 175-198.

Kartal, T. ve Ay, H. (2019). Türkiye'de Faizsiz Finans Kuruluşları Açısından Bir Dönüm Noktası: Faizsiz Finans Muhasebe Standartları (FFMS) Üzerine Bir İnceleme, Uluslararası Bankacılık, Ekonomi ve Yönetim Araştırmalar Dergisi, 2(1), 77-102.

Katılım Bankalarınca Uygulanacak Tekdüzen Hesap Planı ve İzahnamesi Hakkında Tebliğ, 26.01.2007 tarihli 26415 Mükerrer sayılı Resmi Gazete.

KHK/13. 11.11.1975 tarihli 13 sayılı Kanun Hükmünde Kararname, 27.11.1975 tarihli 15425 sayılı Resmi Gazete.

KHK/165. 4.11.1983 tarihli 165 sayılı Kanun Hükmünde Kararname, 4.11.1983 tarihli 18221 sayılı Resmi Gazete.

Mendeş, M. (2012). Uygulamalı Bilimler İçin İstatistik ve Araştırma Yöntemleri, İstanbul, Kriter Yayınları.

Odabaşı, M.(2011). Faizsiz Bankacıllk Eğitim Notları, İstanbul.

Özdemir, M. ve Aslan, H. (2017). Türkiye'de İslami Finansın Dönüşümünün Ekonomi Politiği, İstanbul, Siyaset, Ekonomi ve Toplum Araştırmaları Vakfı (SETA), SETA Yayınları 85. 


$$
\text { S. A. Şenel - Ö. Arslan 12/2 (2020) 1394-1414 }
$$

Özdemir, O., Demirdöğen, Y. ve Oushar, Y.(2019). Faizsiz Finans Muhasebe Standartlarının Mali Tabloların Sunuluşuna Etkileri Üzerine Bir Araştırma, İşletme Araştırmaları Dergisi (Journal Of Busıness ResearchTurk), 11(2), 1151-1171.

Özulucan, A. ve Deran, A. (2009). Katılım Bankacılığı ile Geleneksel Bankaların Bankacılık Hizmetleri ve Muhasebe Uygulamaları Açısından Karşılaştırılması, Mustafa Kemal Üniversitesi Sosyal Bilimler Enstitüsü Dergisi, 6( 11), 85-108.

Özulucan, A. ve Özdemir, F. S. (2010). Katılım Bankacılı̆̆ı, Muhasebe Organizasyonu, Uygulamalar, Finansal Tablolar, Bağımsız Denetim, İstanbul, Türkmen Kitabevi.

Salant, P. and Dillman, D. A. (1994), How to Conduct Your Own Survey, John Wiley \& Sons, Inc. Newyork.

Sellami, Y. M. and Tahari, M. (2017). Factors Influencing Compliance Level with AAOIFI Financial Accounting Standards by Islamic Banks, Journal of Applied Accounting Research, 18(1), 137-159.

SERPAM (2013). Sermaye Piyasaları Araştırma ve Uygulama Merkezi, Araştırma Notları - 1.

Sırım, V. (2013). Türkiye'de Faizsiz Bankacılık Sektörünün Son 10 Yılı ve Beklentiler, Hak İş Uluslararası Emek ve Toplum Dergisi, 2(3), 185-200.

Sufian, F. (2007), The Efficiency of Islamic Bankıng Industry: A Non-Parametric Analysis with Non-Discretınary Input Varıable, Islamic Economic Studies,14(1\&2), 53-87.

T.C. Merkez Bankası Tebliği, 21.03.1984 tarihli 18348 sayılı Resmi Gazete.

Tekdüzen Hesap Planı ve İzahnamesi Hakkında Tebliğ, 26.01.2007 tarihli 26415 Mükerrer sayılı Resmi Gazete.

Tekin, H. (1987). Eğitimde Ölçme ve Değerlendirme, Ankara, Mesa Yayınları.

Ustaoğlu, D. (2014). Türkiye' de Katılım Bankacıllğı Sektördeki Yeri ve Önemi, Adnan Menderes Üniversitesi Sosyal Bilimler Enstitüsü, Yüksek Lisans Tezi, Aydın.

Yatbaz, A. (2019). Faizsiz Bankacılık Fon Kullandırma Yöntemlerinin Uluslararası Muhasebe Standartları Kapsamında İncelenmesi: Bir Alan Çalışması, Marmara Üniversitesi Bankacılık ve Sigortacılık Enstitüsü, Doktora Tezi, İstanbul.

4491 sayılı Bankalar Kanununda Değiş̧iklik Yapılmasına İlişkin Kanun, 19.12.1999 tarihli 23911 sayılı Resmi Gazete

5411 sayılı Bankacılık Kanunu, 01.11.2005 tarihli 25983 Mükerrer sayılı Resmi Gazete.

www.diyanet.gov.tr, Erişim Tarihi: 20.12.2019.

www.kgk.gov.tr, Erişim Tarihi: 17.12.2019.

www.tkbb.org.tr, Erişim Tarihi: 20.12.2019. 